$$
\text { NBER WORKING PAPERS SERIES }
$$

HISTORICAL FACTORS IN LONG RUN GROWTH

\title{
LOUIS BRANDEIS, WORK AND FATIGUE AT THE START OF THE TWENTIETH CENTURY: PRELUDE TO OREGON'S HOURS LIMITATION LAW
}

\author{
Jeremy Atack \\ Fred Bateman
}

Working Paper No. 25

\author{
NATIONAL BUREAU OF ECONOMIC RESEARCH \\ 1050 Massachusetts Avenue \\ Cambridge, MA 02138 \\ May 1991
}

This paper is part of NBER's research program in Development of the American Economy. Any opinions expressed are those of the authors and not those of the National Bureau of Economic Research. 
NBER Working Paper \#25

May 1991

\begin{abstract}
LOUIS BRANDEIS, WORK AND FATIGUE AT THE START OF THE TWENTIETH CENTURY: PRELUDE TO OREGON'S HOURS LIMITATION LAW
\end{abstract}

\begin{abstract}
In the late nineteenth and early twentieth centuries there was considerable interest among the scientific and business communities in the relationship between work, fatigue, health and productivity. Study after study not only documented well-known relationships between occupation and disease such as mercury poisoning among "mad hatters" but also an increasing body of evidence suggested a causal chain between fatigue induced by long hours of work, specific occupational characteristics and weakened resistance to diseases, especially viral diseases such as tuberculosis that posed specific public health, as well as private health, hazards. This evidence first persuaded the Courts to allow limitations upon the hours of work for women on the grounds of protecting the "weaker sex" and the health of future generations as a public health regulation. Eventually such limits were extended to all workers.

In this paper, we analyze the data from an 1892 California Bureau of Labor Statistics survey of 3,493 wage-earners that provides some evidence on the relationship between hours of work and time in a job and worsening health or days of absence from work as a result of ill-health. We conclude that these data support the hypothesis that long hours of work each day in hot and poorly ventilated workshops performing physically or mentally exhausting work at a pace set by inanimate machines was bad for employee health. However, it is hard to make a convincing case for the public regulation of hours and conditions in the workplace as a public, as opposed to a private, health question, except in the case of children, including children in utero, or communicable diseases such as tuberculosis.
\end{abstract}

Jeremy Atack

Department of Economics

University of Illinois

1407 West Gregory Drive

Urbana, IL 61801

and

NBER

Fred Bateman

School of Business

Indiana University

Bloomington, IN 47405 


\title{
LOUIS BRANDEIS, WORK AND FATIGUE AT THE START OF THE TWENTIETH CENTURY: PRELUDE TO OREGON'S HOURS LIMITATION LAW*
}

\author{
Jeremy Atack \\ University of Illinois and National Bureau of Economic Research \\ Fred Bateman \\ Indiana University
}

The intensified work effort associated with the mechanization of industry in the nineteenth century stimulated growing demands for a shorter working day. So long as workers labored alongside the master, taking their pace from him, work hours "from sun to sun" had been tolerable for tasks that were interrupted by inclement weather and seasonality. Such long hours, however, became intolerable when the pace was set by the ceaseless energy of tireless inanimate machines, relieved only by breakdown or maintenance, and under the ever-watchful eyes of supervisors paid to guard against shirking and sabotage and to maximize throughput. One result was increased worker fatigue. In this paper we investigate the proposition that fatigue, induced by long hours of work at arduous, monotonous, or stressful tasks and uninterrupted by regenerative periods of rest, adversely affected the health of workers. Such arguments were made by contemporaries, most effectively by Louis Brandeis, to justify the use of state police powers to interfere in private contracts and limit hours of work as a public health regulation. Most of the quantitative evidence in support of the fatigue-health argument post-dates the adoption of such regulations but here we examine the evidence from a 1892 California Bureau of Labor Statistics survey that could have provided some evidence on the question. ${ }^{1}$

\footnotetext{
We have benefitted from the comments and suggestions of participants at the University of Illinois Economic History Workshop, especially Lee Alston, Royall Brandis, Mary Eschelbach-Gregson and Andrew Seltzer. Research assistance was provided by Andrew Seltzer.

${ }^{1}$ California Bureau of Labor Statistics, Fifth Biennial Report, (Sacramento, California, 1893). These data have been rendered machine-readable by Susan B. Carter, Roger L. Ransom, and Richard Sutch. See Susan B. Carter, Roger L. Ransom, and Richard Sutch, Codebook and User's Manual: Survey of 3,493 Wage Eamers in California in 1892, Reported in the Fifth Biennial Report of the California Bureau of Labor Statistics for 1893, (Berkeley: Institute of Business and Economic Research, 1990)
} 


\section{THE CHANGING NATURE OF WORK AND INDUSTRY}

The nineteenth century witnessed important and far-reaching changes in the nature and organization of industrial production. The substitution of new processes for old and the invention of completely new products brought new and unfamiliar hazards to the workplace. Some, such as unguarded belts and gears or toxic fumes merely threatened the life and limbs of the individual worker. Others, such as dusts and hot humid environments, provided ideal breeding grounds for communicable disesases and thus posed a more general public health risk.

Traditional non-mechanized establishments, especially the larger sweatshops and manufactories, were displaced by mechanized, water or steam-driven plants. ${ }^{2}$ For example, whereas none of the nation's boots and shoes were produced in mechanized plants in 1850, such plants produced almost a quarter of the output by 1870 and while less than a third of the ready-made furniture was produced in mechanized plants in 1850 , two thirds came from such plants by $1870 .{ }^{3}$ In these new mills and factories, the rhythm and pace of work was determined by belts and gears driven by inexhaustible machines instead of by the flex of muscle.

Although the hours that constituted a day's work declined from 12 hours or more in 1830 to about 10 hours by 1880 (Figure 1), shorter daily hours were probably more than offset by the increased intensity of work during those hours and by a reduction in seasonality. The result was a marked increase in what represented a "fair day's work. ${ }^{14}$ Even after allowance for an expected 48 days per year of layoffs, we estimate that in 1880 the average worker was employed over 2,700 hours a year. These hours were worked in a six day workweek that allowed an additional four days off per year_p probably New Year's Day, Good Friday, July 4 and Christmas Day. ${ }^{5}$

\footnotetext{
2 See Kenneth L. Sokoloff, "Was the Transition from the Artisanal Shop to the Non-mechanized Factory Associated with Gains in Efficiency? Evidence from the U.S. Manufacturing Censuses of 1820 and 1850," Explorations in Economic History, 21 (October 1984): 351-82 and Jeremy Atack, "Economies of Scale and Efficiency Gains in the Rise of the Factory in America, 1820-1900" in Peter Kilby (ed) Quantity and Quiddity: Essays in Honor of Stanley L. Lebergott, Wesleyan University Press, (1987), pp. 286-335.

${ }^{3}$ Atack, "Economies of Scale and Efficiency Gains," op. cit.

${ }^{4}$ See, for example, the estimates of labor productivity made by Kenneth Sokoloff. See Kenneth L. Sokoloff, "Productivity Growth in Manufacturing during Early Industrialization: Evidence from the American Northeast, 1820-1860," in Stanley L. Engerman and Robert E. Gallman, Long Term Factors in American Economic Growth, (NBER Studies in Income and Wealth, Volume 51: University of Chicago Press, 1986), pp. 679-729

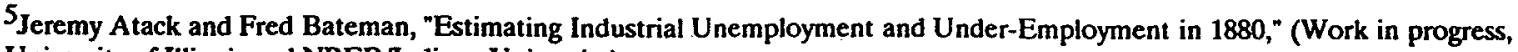
University of Illinois and NBER/Indiana University).
} 


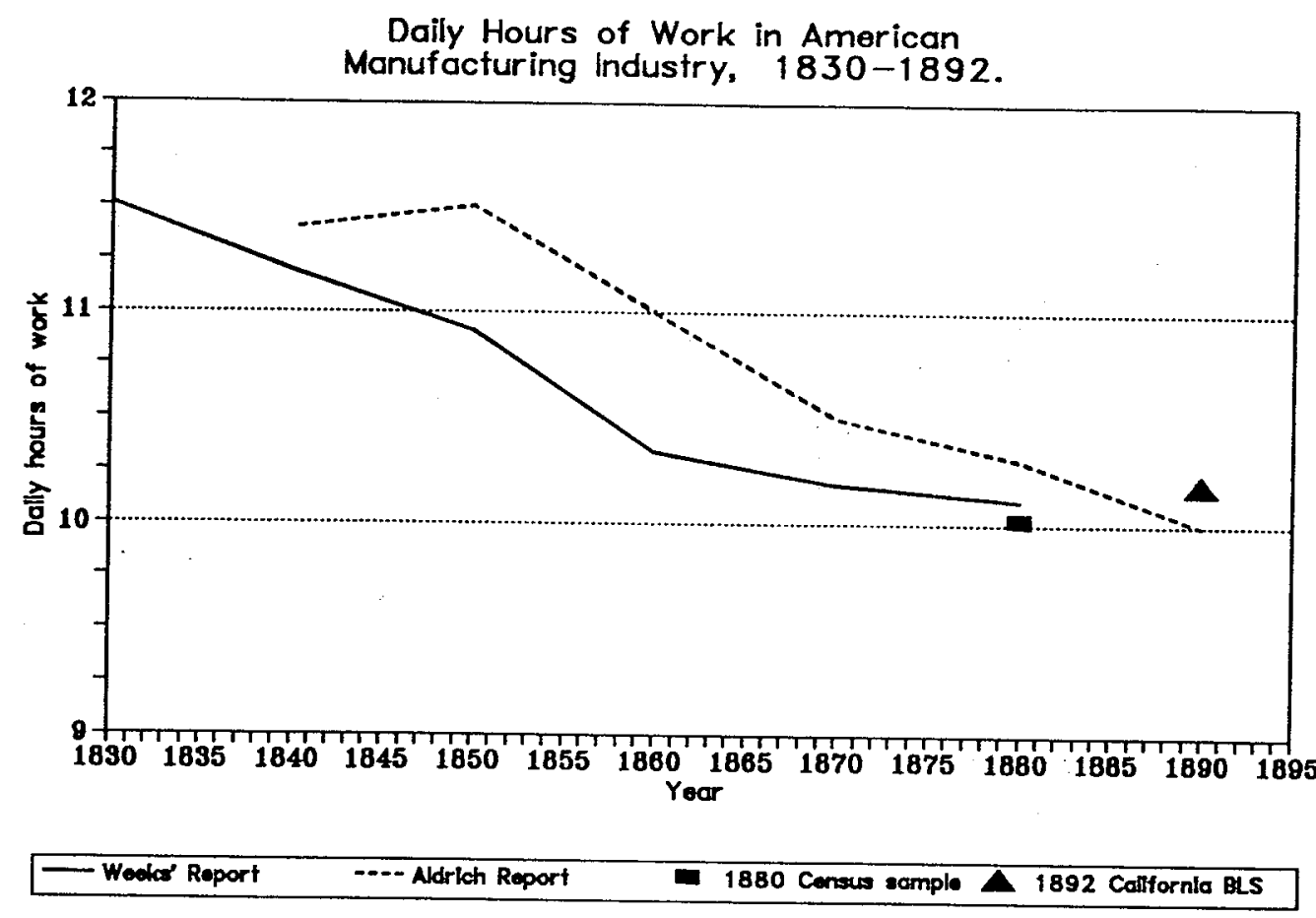

Sources: Weeks Report: US Department of the Interior. Census Office, Report on the Statistics of Wages in the Manufacturing Industries with Supplementary Reports ..., by Joseph D. Weeks, 1880 Census, Volume 20, (Washington DC: GPO, 1883), pp. xxxii-iii. Aldrich Report: Senate Report 1394, 52 Cong., 2d. sess, (1893), "Wholesale Prices, Wages, and Transportation," Table 44, pp. 178-9. 1880 sample: Atack-Bateman National Sample of Firms from the 1880 Census of Manufactures. 1892 California BLS: California Bureau of Labor Statistics, Fifth Biennial Report, (Sacramento, California, 1893).

\section{FIGURE 1}

The centralized nature of steam or water power generation within the plant and the growing interdependence between tasks with increased division of labor led to the imposition of new discipline upon labor. Employers adopted increasingly rigid work rules and enforced them through monitoring and penalties including fines for minor and infrequent infractions and dismissal for more serious and frequent breaches of discipline. For example, by the 1880 s an Illinois Corset factory employing 787 workers had the following rules:

1. Hours of work will be from 7 A.M. to 12 M., and from 1 to 6 P.M.

2. Employes who are five minutes, or over, late will be fined. Those coming after 8 A.M. and 2

P.M. will not be admitted at all;

...

$4 . .$. any one bringing eatables of any description (candies included) into the work-room will be fined; in the case of repetition will be discharged.

...

6. Talking, singing or visiting each other during working hours is strictly forbidden. [Fined at discretion of forewoman.] 
9. Only on presentation of an excuse ticket at the door will employes be permilted to leave the room during working hours ..6 $^{6}$

These draconian work rules probably reflected a job interdependence that rendered the product unfit for its intended use and therefore worthless if just one worker failed to make their individual contribution to the process.

Workers became tied to their machines. As a contemporary observed, Machinery lightens labor, but it requires the operator's constant attention, and the position some have to stand in at machines is little less than punishment. ${ }^{7}$

Moreover, breaks from one's appointed task had to be scheduled or taken when machines required service rather than as needed by the human operator. Man bent to machine; not machine to man. And man often broke from the strain.

Moreover, as the owners moved from the factory floor to front offices and homes, relinquishing day-to-day worker supervision to hired help that was paid for performance, the employers inevitably became less aware of, and less sympathetic to, the condition and concerns of wage-earners in their employ. Such indifference was a perfectly rational response so long as the supply of labor was elastic (and the late nineteenth century surge in immigration certainly helped in this respect), investment in firm- and job-specific training was minimal and employers were not held liable for damages for the impaired health or loss of life of their employees.

\section{THE NEW STRAIN IN INDUSTRY 8}

Although the substitution of inanimate for animate sources of power and the use of machinery did much to reduce the premium on physical strength in many tasks, they did little to mitigate the physical and mental endurance necessary to complete a day's work. Indeed, they often created new strains. Heavy machinery created a cacophony. Drive shafts set up vibrations. High speed machinery demanded quick, deft operatives. Motions were repetitive. Eyes were strained by poor light, rapid movement and

\footnotetext{
6Illinois. Bureau of Labor Statistics, Fourth Biennial Report, (Springfield, Illinois: H. W. Rokker, 1886), p. 503-4.

${ }^{7}$ Ohio. Bureau of Labor Statistics, Second Annual Report of the Bureau of Labor Statistics, (Columbus: Nevins and Myers, 1879), p. 283

${ }^{8}$ This sub-heading is taken from Josephine Goldmark, Fatigue and Elficiency, (New York: Russell Sage Foundation, 1913), p. 43 to which the reader is referred for many additional and different examples from those given here.
} 
airborne material. And above all, workers had to keep their wits about them to avoid the whipping belts, whirring gears and myriad other devices that threatened life or limb.

The result was a marked deterioration in working conditions and increased strain despite the shorter working day:

\begin{abstract}
The constant nervous tension from continued exertion in a modern factory or workshop for a period of ten hours is a severe strain upon the physical system. Work is not done in the old, slow way, and in nearly all industries, by the present methods from two to four times the quantity of product is turned out in the ten hours. How much faster is the operative compelled to work, and how much greater is the strain, to accomplish this amount of work, in comparison with the old twelve-hour method. ${ }^{9}$
\end{abstract}

Certainly, horrific pictures are painted of contemporary working conditions even if one discounts the yellow journalism of The Jungle. ${ }^{10}$ Consider, for example, conditions in a steel mill:

\begin{abstract}
there is always a fine dust in the air of a steel mill ... [of ] minute, shining grains. A visitor experiences no ill-effect after a few hours in a mill but the steel workers notice it and ... the irritation of the throat and air passages caused by this mineral dust may lead to catarrh or even to tuberculosis. 11
\end{abstract}

These dusts to the extent that they made breathing difficult increased worker fatigue. They pervaded many workplaces. All were dangerous to health but none more so than those from metal and mineral grinding and polishing (Figure 2). These caused serious scarring of the lung tissue providing an ideal pathway for the entry of the tuberculosis bacillus. Animal dusts like those of bone, mother of pearl and hair were almost as bad. Leather and vegetable dusts were less dangerous but prolonged exposure was still associated with a variety of respiratory infections (Table 1). ${ }^{12}$ Tuberculosis is highly contagious and was implicated in perhaps half of the deaths in the late nineteenth and early twentieth centuries among industrial workers. ${ }^{13}$ "Promiscuous expectoration," particularly among a closely confined and alreadyweakened and susceptible (i.e. fatigued) population, quickly transmitted the disease from worker to worker. More than any other single health risk, it posed a clear and present danger to public health. Education and improved sanitation could dramatically reduce that risk. For example, in Solingen (Germany), tuberculosis mortality was reduced from 20.6 per 1,000 in 1885 to 9.3 per 1,000 in 1910 in

${ }^{9}$ Maine. Bureau of Industrial and Labor Statistics, Sixth Annual Report of the Bureau of Industrial and Labor Statistics for the State of Maine: 1892, (Augusta: Burleigh \& Flynt, 1893), p. 11.

${ }^{10}$ Upton Sinclair, The Jungle, New York, 1906.

${ }^{11}$ John Fitch, The Steel Workers: The Pittsburgh Survey, (New York: Russell Sage Foundation, 1910), p. 58.

${ }^{12}$ C. A. E. Winslow, The Health of the Worker: Dangers to Health in the Factory and How to Avoid Them, (Metropolitan Life
Insurance Co., 1913) ${ }^{13}$ George M. Kober and William C. Hanson (eds.), Diseases of Occupation and Vocational Hygiene, (Philadelphia: P. Blakiston's Son \& Co., 1916), p. 426. 
part by education about the public health hazards of coughing and convenient placement of cuspidors. ${ }^{14}$ In the U.S., the tuberculosis rate among 472,000 workers in 15 occupations that exposed them to organic dusts was 2.29 per 1,000 compared with 1.55 per 1,000 in the population at large..$^{15}$

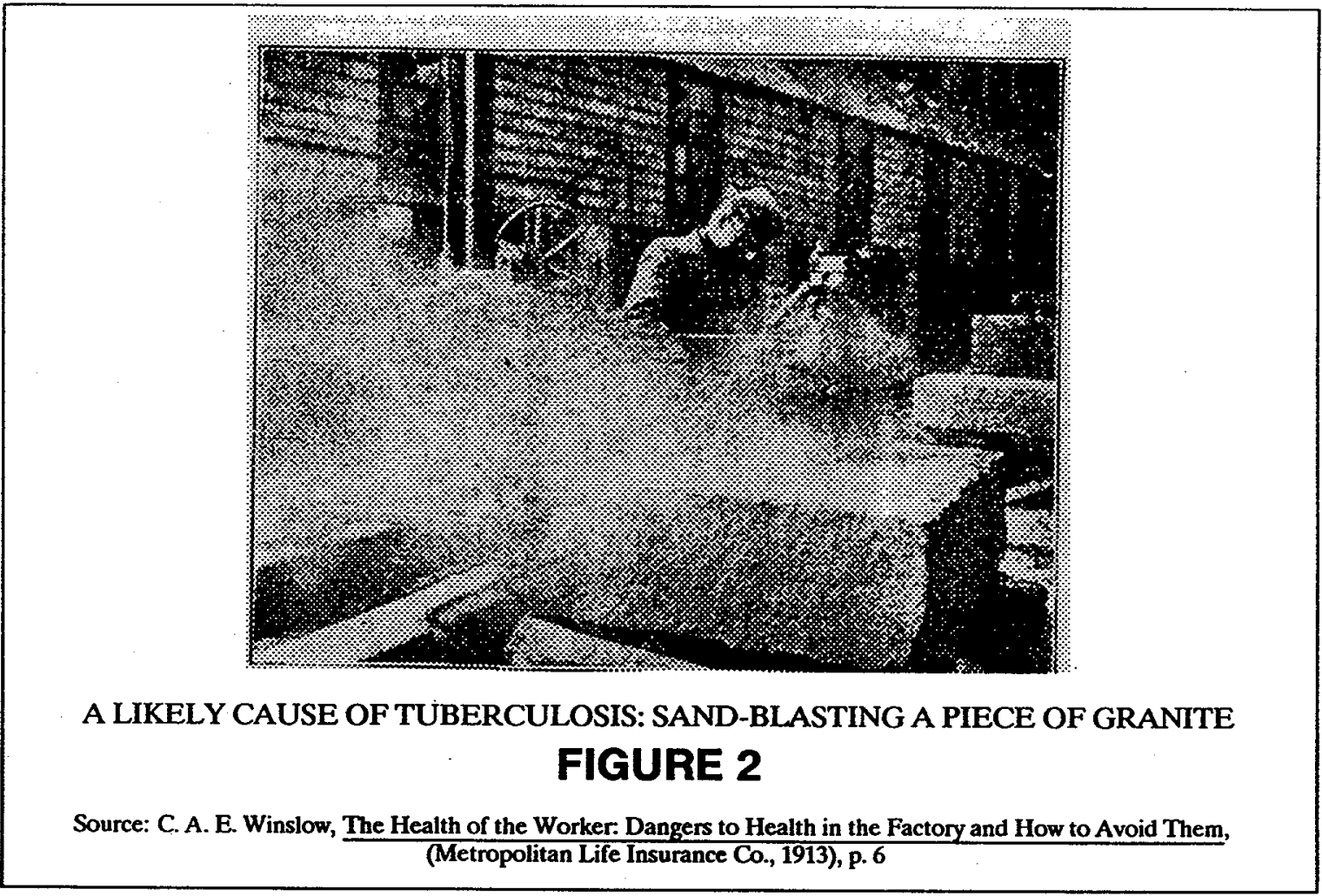

\section{TABLE 1}

Morbidity from Tuberculosis and Pneumonia in Dusty Occupations Compared with Non-dusty Occupations. (deaths per 1,000)

\begin{tabular}{lrr}
\hline \hline Dust exposure & Tuberculosis & Pneumonia \\
\hline Metal dust & 28.0 & 17.4 \\
Mineral dust & 25.2 & 5.9 \\
Mixed dusts & 22.6 & 6.0 \\
Animal dusts & 20.8 & 7.7 \\
Vegetable dusts & 13.3 & 9.4 \\
\hline No dust exposure & & 4.6 \\
\hline \hline
\end{tabular}

Source: George M. Kober and William C. Hanson (eds.), Diseases of Occupation and Vocational Hygiene, (Philadelphia: P. Blakiston's Son \& Co., 1916), p. 427.

\footnotetext{
14 Ibid., p. 428.
} 
Most other hazards of the workplace simply posed a threat to the individual worker:

... the men with whom I talked were often a little hard of hearing. It was some time before I connected this fact with the noise of the mill. The rolling mills are all noisy, the blooming mills and plate mills especially so, while the cold saw bites into the steel with a screech that is fairly maddening. ... This noise has an effect also on the nerves, which is intensified by the constant vibration of the machinery; a strain more wearing on some of the men than the work itself. 16

These conditions were exacerbated by high temperatures, not only around the furnaces but also in the rolling mills where:

the floor plates become heated by the hot steel continually passing over them. I have seen men standing on floors so hot that a drop of water spilled would hiss like a drop on a stove. The shoes with thick wooden soles that they wear, act as some protection, yet their feet are heated to the point of great discomfort; and this is a thing that they must encounter every day and for from eight to twelve hours, practically without relief. 17

In open-hearth works, workmen banking with dolomite were exposed to temperatures in excess of $220^{\circ} \mathrm{F}$ for more than two minutes. ${ }^{18}$ Men also had to work for extended periods of time 6 or 7 feet from partially-opened furnace doors where temperatures exceeded $150^{\circ} \mathrm{F} \cdot{ }^{19}$ In addition to the ambient heat from furnaces, those dealing with red-hot metal also had to contend with radiant heat and temperatures that could be well in excess of those of the surrounding air. Steel workers, however, were not the only ones who worked under temperature extremes. Laundry workers; especially those ironing and starching experienced $95^{\circ}$ conditions; those working in evaporator rooms in sugar refineries, $110^{\circ}-115^{\circ}$; and those manufacturing oxygen, $100^{\circ}-120^{\circ} \mathrm{F} .^{20}$

Conditions in many other branches of industry seem no less tiring. For example,

in the making of hinges a woman lifts a half-formed hinge, places it in the bending machine and quickly withdraws her hand, and repeats this series of movements at a rate of 50 times a minute, or 30,000 times a day. The tops of tin cans are cut by pressing the lever of a foot press 40 times a minute, 24,000 times a day. 21

$15_{\text {Ibid., p. } 427 .}$

${ }^{16}$ Fitch, The Steel Workers, op. cit., p. 58.

$17_{\text {Ibid., p. } 60 .}$

18U.S. Congress. Senate, "Report on Conditions of Employment in the Iron and Steel Industry, Volume III", 62d Cong., 1 sess., Document No. 110 (1913), pp. 289-332 especially p. 313 . The source notes that at this temperature they were unable to get an accurate reading.

${ }^{19}$ lbid., also Kober and Hanson, Diseases of Occupation, op. cit., p. 588.

20U.S. Supreme Court, BUNTING v. OREGON, 243 U.S. 246, 37 Sup. Ct. (1917), "The Case for the Shorter Work Day. Brief for Defendant in Error," vol. 1, p. 245.

$21_{\text {Ibid., p. } 204 .}$ 


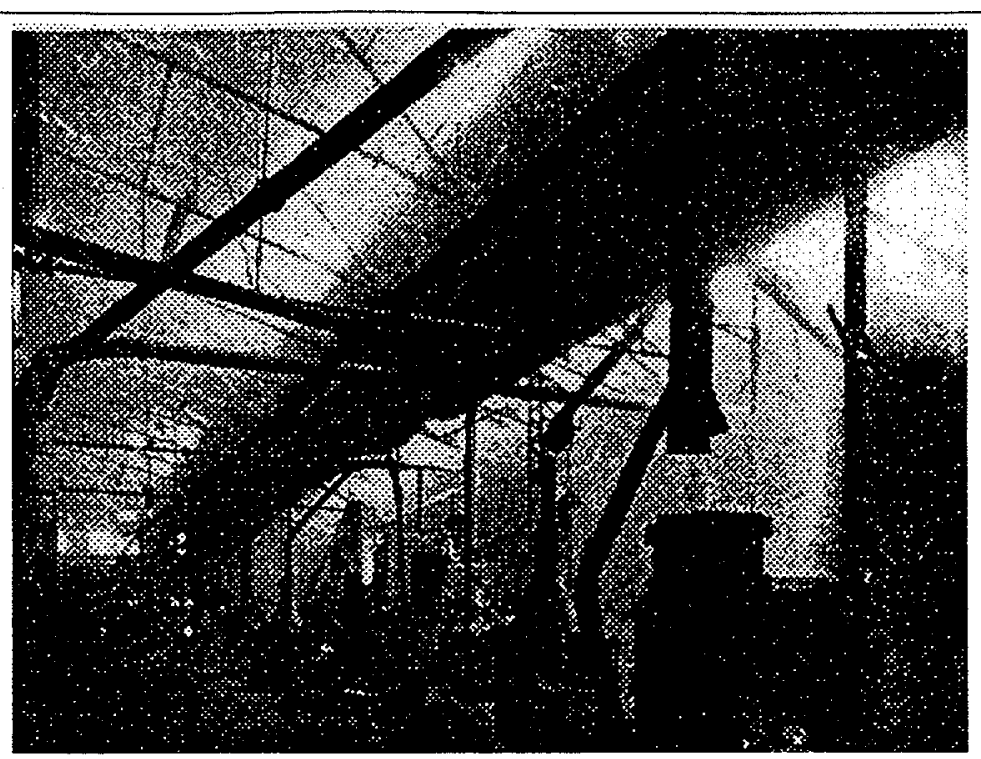

\section{DUST AND FUMES IN THE AIR OF A TURN OF THE CENTURY WORKROOM FIGURE 3}

Source: C. A. E. Winslow, The Health of the Worker: Dangers to Health in the Factory and How to Avoid Them, (Metropolitan Life Insurance Co., 1913), p. 4

Or consider some of the jobs in a boot and shoe factory:

The trimming machine consists of a sharp knife edge, operating constantly against a sharp edged revolving top. The man who works the machine stands, holding upside down somewhat below the level of his eyes, the partly made, still unsoled shoe. He turns it skilfully and rapidly on the revolving top, against whose sharp edge the second knife-blade operates, cutting off all the surplus crimped leather. The work is extremely rapid and absolutely uniform. But it takes skill and close attention. The machine could easily cut off. too much, or could cut into the upper [or fingers!_ authors] if the swift handling of the shoe were not exactly correct.

... The next example is women's work. It is the operation of the new eyeletting machines, which move with what the makers rightly describe as "bewildering rapidity." The girl who operates this machine sits in front of it, guiding the flat sewn uppers, which are to have eyelets punched into them, somewhat as she would guide the material in a sewing machine. She adjusts levers and various mechanical contrivances to regulate the speed and spacing of the eyelets. 22

Both jobs were paid by the piece. A trimmer might handle 2,600 pair per day; an eyeletter, 2,000 pairs or more depending upon the number of eyelets to be punched. ${ }^{23}$ At rates prevailing in Lynn in 1915, however, an eyeletter had to handle between 33,000 and 50,000 pairs, requiring from perhaps 4 eyelets

${ }^{22}$ Goldmark, Fatigue, op. cit., pp. $65-6$.

$23_{\text {Ibid. }}$ 
per shoe for men's shoes to as many as 12 for women's boots, to earn $\$ 10$ or approximately the average weekly wage for women in the industry. ${ }^{24}$

\section{HOURS OF WORK, FATIGUE AND ILL-HEALTH.}

Such working conditions led to fatigue_- something that we are all familiar with but one which defies a precise universally-accepted definition. ${ }^{25}$ The simplest definition of fatigue as "the sum of the results of activity which show themselves in a diminished capacity for doing work" 26 misses important aspects of the phenomenon, particularly those that are of interest to us here. P. Sargant Florence uses a somewhat broader concept: "fatigue may be defined . . . as a diminution of working capacity, often accompanied by feelings of weariness, caused in the human organism by the length or intensity of some activity. ${ }^{27}$ We have adopted a more inclusive definition of fatigue that identifies three phenomena:

First, the changes in level of performance expressed in decreased capacity for work, which might be called objective fatigue. ... Second, the physiological changes due to the chemical products of fatigue, which might be call physiological fatigue. The metabolic rate of energy consumption measures this real basis for physical fatigue and also mental fatigue in so far as it can be determined physiologically. Third, the feeling of fatigue in ennui, bodily weariness, tiredness, dissatisfaction or boredom, which might be referred to as subjective fatigue. 28

Some aspects of fatigue, such as the accumulation of toxins in muscles (physiological fatigue) or diminished productive capacity (objective fatigue), naturally lend themselves to measurement and have been exhaustively studied particularly in Great Britain as a result of efforts to increase production during the First World War. ${ }^{29}$ They were also a matter of concern during the Second World War. ${ }^{30}$ Subjective fatigue, however, is less easily measured but tends to be cumulative and to react on the health

${ }^{24}$ U.S. Department of Labor. Bureau of Labor Statistics, "The Boot and Shoe Industry in Massachusetts as a Vocation for Women," Bulletin 180, (Women in Industry Series No. 7), (Washington DC: Government Printing Office, October 1915), p. 69.

${ }^{25}$ See S. Howard Bartiey and Eloise Chute, Fatigue and Impairment in Man, (New York: McGraw-Hill, 1947), especially Chapter 2, pp.5-46.

${ }^{26}$ Ministry of Munitions. Health of Munition Workers Committee, "Industrial Fatigue and Its Causes, Cmd. 8213, (London: His Majesty's Stationary Office, 1916), p.3.

27Philip Sargant Florence, "Use of Factory Statistics in the Investigation of Industrial Fatigue: A Manual for Field Research," Ph.D dissertation, Columbia University, 1918, p. 15.

${ }^{28}$ Daniel Starch, Hazel M. Stanton and Wilhelmine Koerth, Controlling Human Behavior, (New York: Macmillan, 1936), p.202.

${ }^{29} \mathrm{See}$, for example, Bartley and Chute, Fatigue and Impairment, op. cit.; Goldmark, Fatigue and Efficiency, op. cit.; P. Sargant Florence, The Economics of Fatigue and Unrest, (London: George Allen \& Unwin, 1924); H. M. Vernon, Industrial Fatigue and Efficiency, (London: Routledge, 1921); Frederic S. Lee, The Human Machine and Industrial Efficiency, (New York: Longmans, 1919); Great Britain. Medical Research Council and Department of Scientific and Industrial Research, Annual Reports of the Industrial Fatigue Research Board, (London: His Majesty's Stationary Office, 1920-29) and Great Britain. Medical Research Committee and Department of Scientific and Industrial Research, Reports of the Industrial Fatigue
Research Board, (London: His Majesty's Stationary Office).

${ }^{30}$ See, for example, New York. Department of Labor. Division of Women in Industry and Minimum Wage, "Hours of Work in Relation to Health and Efficiency," (typescript, August 1941) 
of the worker. A worker losing his or her health will lose some degree of their productive capacity and earnings capacity and they may lose it entirely until their health is regained..$^{31}$ Ill-health, however, is not solely the product of fatigue and so the relationship between fatigue and ill-health is less than perfect. Nevertheless, there is substantial agreement that such a link exists:

One of the important predisposing causes to disease is overwork or fatigue, because the accumulation of waste products in the blood, from muscular wear and tear, together with the expended nervous energy, combine to render the system more susceptible to disease. Excessive work is inimical to health, and long hours and hard work are calculated to diminish the general power of resistance, and thus bring about physical deterioration. 32

Minor ailments prove to have an unsuspected importance when considered as gateways to serious illness ... The typical succession of events is first fatigue, then colds, then tuberculosis, then death. 33

Even ... where specific diseases cannot be traced directly to the fatigue of labor, it is undoubted that industrial overwork often occurs and puts the worker into a physical condition . .. wherein his physiological mechanism is in a state of depression and ready to fall a prey to specific maladies. 34

You will find that fatigue has a larger share in the promotion or permission of disease than any other single causal condition you can name. ${ }^{35}$

The accumulated results of fatigue are damaging to general health and they will be reflected in the sickness returns. 36

Concrete evidence (outside of specific occupational diseases such as brown lung, mercury poisoning among hatters, "phosy jaw" and plumbism) is, however, hard to find although Vernon cites some evidence from a 9.2-inch shell factory that he studied (Figure 4). Men lost 7 percent of their time from sickness while working 63.5 hours a week, but only 4 percent when working 54 hours. Women lost 4.3 percent of their time to sickness at 54 hours per week but only 2.8 percent on a 44.5 hour week..$^{37}$

A similar phenomenon was noted by P. Sargent Florence in an English engineering plant that employed over 1,000 workers. In August 1915, scheduled hours averaged 46 a week and workers lost an

${ }^{31}$ Vernon, Industrial Fatigue, op. cit., p. 2.

${ }^{32}$ U.S. Department of Labor. Bureau of Labor Statistics, "Industrial Hygiene," Bulletin, 75 (March 1908), p. 536.

33 National Conservation Commission, Bulletin of the Committee of One Hundred on National Health, (July 1909 ), p. 47. Report on National Vitality

${ }^{34}$ Kober, Diseases of Occupation, op. cit., p.259.

${ }^{35}$ Ministry of Munitions. Health of Munition Workers Committee, "Sickness and Injury," Memorandum No. 10, Cmd. 8216, (London: His Majesty's Stationary Office, 1916), p. 4.

36 Ministry of Munitions. Health of Munition Workers Committee, "Industrial Fatigue and Its Causes," Memorandum No. 7, op. cit. p. 9.

${ }^{37}$ Great Britain. Medical Research Committee and Department of Scientific and Industrial Research, The Speed of Adaptation of Output to Altered Hours of Work," Reports of the Industrial Fatigue Research Board No. 6, (London: His Majesty's Stationary Office, 1920), p. 31. 
average of 2.8 percent of this time from sickness. In September and October, pressure from war orders led to an increase in hours to $49 \frac{1}{2}$ and then to 53 per week. Time lost through sickness rose to 3.2 percent and then to 3.85 percent. In November and December, hours were cut; first to $51^{\frac{1}{2}} \frac{1}{2}$ and then to $46^{\frac{3}{2}}$ per week. Time lost through sickness declined to 3.1 percent and then to 2.77 percent during this same period. ${ }^{38}$

Time Lost Through Sickness at a British Ordinance Factory, 1916-1917

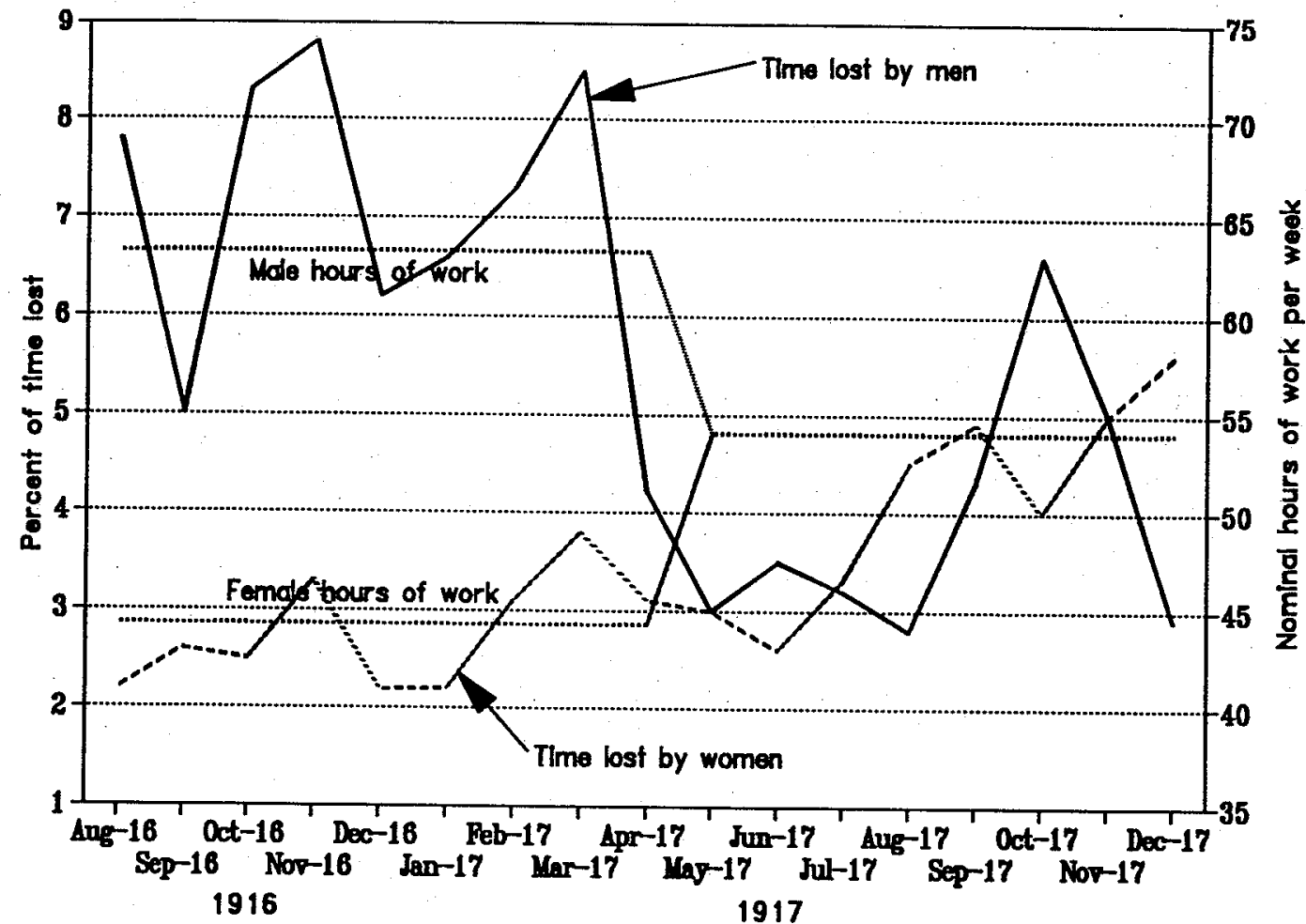

Source: Great Britain. Medical Research Committee and Department of Scientific and Industrial Research, "The Speed of Adaptation of Output to Altered Hours of Work, " Reports of the Industrial Fatigue Research Board No. 6, (London: His Majesty's Stationary Office, 1920), p. 31.

\section{FIGURE 4}

Lastly, a Women's Bureau study of lost time and labor turnover in cotton mills concluded that "changes in the absense, sickness and turnover rate under various conditions would probably be more significant [of fatigue] than a measurement of ... output." ${ }^{19}$ The women textile workers studied lost an ${ }^{38} \mathrm{P}$. Sargent Florence, The Economics of Fatigue and Unrest and the Efficiency of Labour in English and American Industry,
(London: George Allen \& Unwin, 1924), p. 329.

${ }^{39}$ U.S. Department of Labor. Women's Bureau, "Lost Time and Labor Turnover in Cotton Mills," Bulletin No. S2, (Washington DC: Government Printing Office, 1926), p. 10. 
average of 6.0 percent of their time due to their own sickness while working a 48-hour week; 7.1 percent of their time when working 48-54 hours; 13.5 percent working 55 hours and 14.1 percent when working a 55 to 60 hour work week. . $^{40}$

\section{The Relationship Between Long Hours of Work and Health}

RENFORCNG FACTORS:

1. Speed

2. Monotony

3. Repetitive motion

4. Physical exertion

5. High temperotures and humidity

6. Low femperatures

7. Physled danger

8. Eyestrain

9. Mental stroin

a. Group characterlatics (e.g sex, oge, environment)

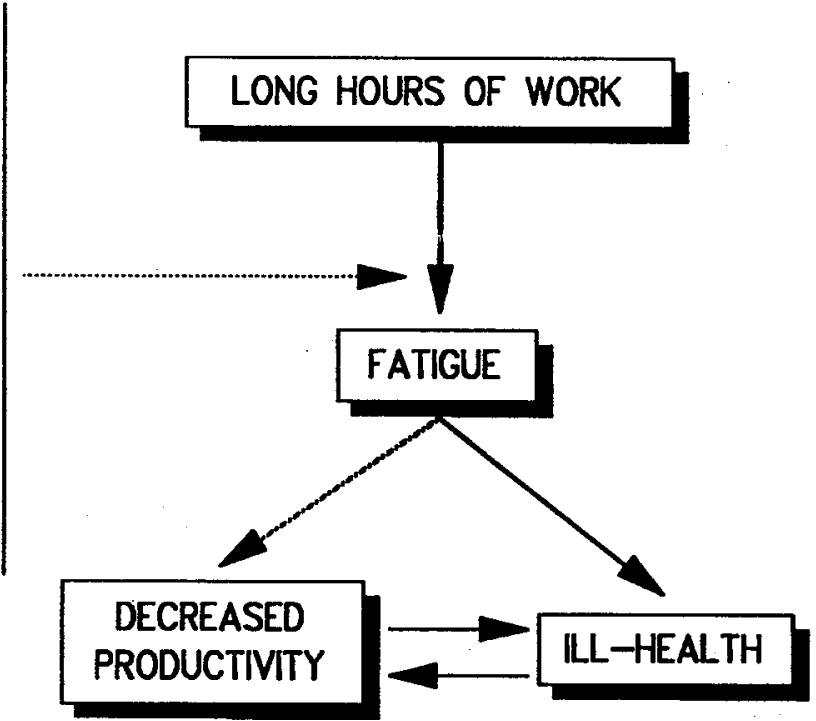

FIGURE 5

The model that underlies our analysis (Figure 5) is that long hours of work each day were exacerbated by adverse working conditions such as speed, noise, monotony, physical or mental strain and led to fatigue that was hastened and worsened by group characteristics such as sex, age, nutritional and general health. Fatigue, in turn, led to ill-health and decreased productivity that were mutually reinforcing. Our focus here is upon ill-health as measured by days lost through sickness, subjective assessments of general health, and subjective assessments of the change in general health. Evidence on the productivity effects of long hours of work in the late nineteenth century is presented elsewhere. ${ }^{41}$

\footnotetext{
40 Tbid., p. 83.

${ }^{41}$ See Jeremy Atack and Fred Bateman, "Were Hours of Work "Too Long" in 1880? The Effects of Long Hours on Labor Productivity," (Work in progress, University of Illinois and NBER/Indiana University)
} 


\title{
HOURS OF WORK: THE LEGISLATURE
}

The link between long hours of work, fatigue and health was crucial to the legal outcome of court challenges to laws limiting hours of work. It provided the justification for the use of the police powers of the state to enforce_as a public health measure_laws that otherwise were unconstitutional.

Early efforts to secure shorter hours had relied upon contract negotiations between employees and individual employers, reinforced by the occasional strike threat or strike. ${ }^{42}$ This strategy, however, seems to have borne little fruit. Employers were apparently extremely reluctant to reduce hours even though they might have attracted a superior workforce as a result. It is unlikely that technological considerations such as the demands of continuous production or the time needed to process a batch explain this unwillingness to consider shorter hours. Instead, the anecdotal evidence suggests two reasons. First, many in the business community seem to have accepted Nassau Senior's erroneous argument that the entire profits of an enterprise were made in the eleventh hour. ${ }^{43}$ This lends credence to John Maynard Keynes' rhetorical closing statement in The General Theory that

\footnotetext{
the ideas of economists ... both when they are right and when they are wrong, are more powerful than is commonly understood. Indeed the world is ruled by little else. Practical men, who believe themselves to be quite exempt from any intellectual influences, are usually the slaves of some defunct economist. 44
}

Second, employers expressed serious reservations about the use to which additional leisure time would be put. For example, a furniture manufacturer from Ohio opined

\begin{abstract}
the majority of men are like boys, the less they have to do the more time they put in deviltry. Give them plenty to do and a long time to do it in, and you will then find them physically and morally better. ${ }^{4}$.
\end{abstract}

A carriage manufacturer thought that "when they are at work they are out of mischief,"46 and a leather manufacturer remarked that they already "have all the time to swill all the beer they want. ${ }^{47}$ Nor were things apparently any different on the East Coast where Carroll Wright summed up one set of

\footnotetext{
${ }^{42}$ For example, in 1881,814 of the almost 3,000 strikes were for a reduction in hours of work while in $1890,2,001$ of the 9,424 strikes were for shorter hours.

${ }^{43}$ See Nassau W. Senior, Letters on the Factory Acts, 2d. edition (London: B. Fellowes, 1844), pp. 1ff.

${ }^{44}$ John Maynard Keynes, The General Theory of Employment Interest and Money, (London: Macmillan, 1960), p. 383.

${ }^{45}$ Ohio. Bureau of Labor Statistics, Second Annual Report, op. cit., p. 281.

${ }^{46}$ Ibid.

47Ibid., p. 282.
} 
objections to shorter hours in three words, "Whiskey, Tobacco, Loafing." ${ }^{48}$ Some workers even expressed doubts about their own or their fellow-workers' use of increased leisure time. One responded "Waste it, what else?" another "Loaf around the streets and at home as I do now."49 Yet others said things such as "Women would promenade and gossip," and "Two-thirds of the men would spend it where they could get something to drink. ${ }^{50}$ The problem, however, as Wright saw it was not that most workers would make poor use of increased leisure time but rather that the manager's "first thought concerning less hours is that it would only be an opportunity for his most troublesome employees to be even more troublesome. ${ }^{.51}$

Given these attitudes and the resistance to the voluntary adoption of a shorter working day, it is not surprising that employees sought to engage the coercive powers of the state in their quest. For example, petitions were presented to the Massachusetts legislature in 1842,1843, and 1844 seeking passage of a ten-hour law but nothing came of them. ${ }^{52}$ In 1847 , however, the New Hampshire legislature passed the first law setting hours of work. It established 10 hours as a legal day's work for everyone and provided that no person could be required to work longer "except in pursuance of an express contract requiring a greater time." 53 There were no provisions for enforcement or penalties for violators. Nevertheless, just three days before the law was to go into effect, many New Hampshire manufacturers submitted the necessary express contracts to their employees. All who refused to sign_-including between one half and two-thirds of the operatives at the Nashua Corporation (one of the largest firms in the state)_—were fired and replaced..$^{54}$

Similar laws were also passed in other states__Pennsylvania (1848), Maine (1848), New Jersey (1851), New York, (1853), Rhode Island (1853), California (1853), Georgia (1853), and Connecticut

\footnotetext{
${ }^{48}$ Massachusetts. Bureau of Labor Statistics, Twelfth Annual Report, (Boston: Rand, Avery \& Co., 1881), Public Document No. 15, Part III, "Uniform Hours of Labor," pp. 323-475, especially p. 467.

${ }^{49}$ Ibid.

$50_{\text {Ibid. }}$

$51_{\text {lbid., p. } 468 .}$

52 Charles E. Persons, "The Early History of Factory Legislation in Massachusetts From 1825 to the Passage of the Ten Hour Law in 1874," in Susan Kingsbury (ed.), Labor Laws and Their Enforcement with Special Reference to Massachusetts, (Longmans for the Women's Educational and Industrial Union, 1911) pp. 1-129. especially pp. 24-27.

53 New Hampshire, 1847 Session Laws, Ch. 4.

${ }^{54}$ U.S. Congress. Senate, "History of Women in Industry," 61st Cong., 2d Sess, Document 645, op. cit., p. 69 quoting Voice of Industry, 3 September 1847 and Voice of Industry, 17 September 1847. See also Commons and Andrews, Principles of Labor Legislation, op. cit., p. 248.
} 
(1855). ${ }^{55}$ Although many established penalties for violators, all retained the provisions guaranteeing the primacy of existing contracts and refusing to impose limits upon future agreements.

In 1852, Ohio became the first state to enact legislation specifically limiting the hours of work for women. The law provided that women could not be compelled to work longer than ten hours a day under penalty of a $\$ 5$ to $\$ 50$ fine. ${ }^{56}$ Although this stipulation supposedly rendered the law ineffective, it did not prevent the adoption of similar laws by Minnesota, Wisconsin, and Dakota. 57

Massachusetts, which had been the focus of vigorous and long-term labor lobbying to pass a tenhour law, was a relatively late-entrant but her law became the model for all subsequent legislation. That law established statutory limitations upon the hours that women could work by prohibiting the employment of women for more than ten hours a day except to make up time lost by breakdowns or to secure a shorter working day sometime during the week and in no case were their hours to exceed sixty in any one week. ${ }^{58}$ In addition, the law forbad employees from contracting out of the provisions either at their own or their employers behest and all existing labor contracts calling for longer hours were invalidated.

This law survived legal challenge and became the model for subsequent laws including those sustained by the U.S. Supreme Court. For example, in the late 1880 s Maine passed a similar law. However, even by 1896 , only 13 states had passed any kind of law restricting women's hours and of these one had been declared unconstitutional by the state supreme court: 59 Only Maine, Massachusetts and New Jersey had laws thought to be effective. 60

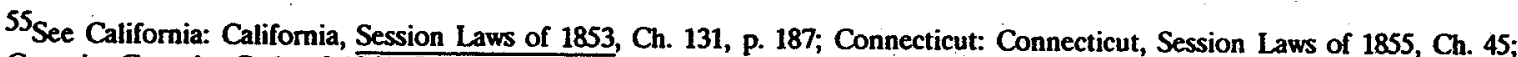
Georgia: Georgia, Code of 1861, Sec. 1847; Maine: Maine, Session Laws 1848, ch. 83; New Jersey. New Jersey, Session Laws 1851, pp. 321-322 (This law only applied to cotton, woolen, silk, paper, glass, and flax factories and to iron and brass works); New York: New York, Session Laws 1853, ch. 641; Pennsylvania: Pennsylvania, Session Laws 1848, Act 227; Rhode Island: Rhode Island, Session Laws 1853, p. 245.

56 Ohio, Session Laws 1852, v. 50, p. 187.

57Dakota: Dakota Territory Legislature. Dakota Session Laws 1862-3, ch. 49; Minnesota: Minnesota, Session Laws 1858, ch. 66; Wisconsin: Wisconsin, Session Laws 1867, ch. 83.

${ }^{58}$ Massachusetts, Laws 1874, C. 221.

59 RICHIE V. PEOPLE. 155 III. 98 (1895).

${ }^{60}$ Elizabeth Brandeis, "Labor Legislation," in Commons et al., History of Labour, op. cit., IV, 457.
} 


\section{HOURS OF WORK AND HEALTH: THE COURTS}

It is claimed that the loophole provided by the contracting-out provision of the declaratory laws establishing eight or ten hours as a legal day rendered them ineffective. ${ }^{61}$ This would seem doubly so since the Courts assumed the existence of a contract superseding the law whenever customary hours were longer. ${ }^{62}$ There was, however, a very sound legal reason why the laws were framed as they were: without the loophole these laws could be viewed as an unconstitutional interference with the right to free contracting. Nor was this legal construct regarding constitutionality unreasonable: In 1905, the U.S. Supreme Court in LOCHNER v. NEW YORK struck down a New York state law setting maximum hours for bakers. ${ }^{63}$ The law was held invalid as an unreasonable interference with the right of free contract and an excessive use of the police powers of the state.

However, the Massachusetts law was sustained by the courts. Why? The magic formula in the Massachusetts law was the argument that since the health of future generations depended upon the health of the mothers the regulation of hours of work for women fell within the police powers of the state as a public health regulation-a view with which the courts concurred. In the case of COMMONWEALTH V. HAMILTON MANUFACTURING COMPANY ${ }^{64}$ the Massachusetts Supreme Court ruled that:

[The 1874 law] merely provides ... no person shall be engaged in labor more than ten hours a day or sixty hours a week. There can be no doubt that such legislation be maintained either as a health or police regulation ... This principle has been so frequently recognized in this Commonwealth that reference to the decisions is unnecessary. 65

The decision was not appealed to the U.S. Supreme Court, but in 1908 the U.S. Supreme Court reached essentially the same decision in MULLER $v$. OREGON affirming that such laws were reasonable uses of police power. ${ }^{66}$ By 1921 all but four states had adopted such laws. ${ }^{67}$

\footnotetext{
${ }^{61}$ See, for example, Commons, et al., History of Labour, op. cit., IV, p. 541.

62 HELPHENSTEINE V. HARTIG (5 Ind. App. Ct. 172, 1892).

$63_{198}$ US 45, 28 Sup Ct. 539 (1905).

${ }^{64}$ COMMONWEALTH V. HAMILTON MANUFACTURING COMPANY, 120 Mass. 383 (1876).

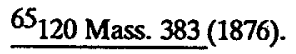

${ }^{66}$ Before the U.S. Supreme Court ruling, at least four state courts had sustained such legislation: COMMONWEALTH V. HAMILTON MANUFACTURING COMPANY, 125 Mass. 383; WENHAM V. STATE, 65 Neb. 394, 400, 406; STATE V. BUCHANAN, 29 Wash. 602; COMMONWEALTH V. BEATTY, 15 Pa. Sup. Ct. 5, 17. For the U.S. Supreme Court decision, see MULLER v. OREGON, 208 US 412.

67John R. Commons and John B. Andrews, Principles of Labor Legislation, (New York: Harper \& Brothers, 1927), p. 249.
} 
In MULLER v. OREGON, the state of Oregon had brought suit against Curt Muller, the operator of a Portland laundry, for violation of a 1903 Oregon law that "no female [shall] be employed in any mechanical establishment or factory or laundry . . . more than ten hours in any one day." 68 Muller was convicted in state Circuit Court in September 1905 and fined $\$ 10$. The case was appealed to the Oregon Supreme Court which affirmed the decision. ${ }^{69}$ Muller subsequently appealed to the U.S. Supreme Court on the grounds that the law violated his 14th Amendment rights under the Constitution by the taking of liberty and property without due process and the denial of equal protection.

The counsel for the defense was Louis D. Brandeis who prepared the now-famous, winning brief_- "the Brandeis Brief." 70 This was a document of some 112 pages presenting, in part, a mixture of opinion and scientific evidence from the U.S. and Europe that long hours of work were harmful to health, safety, public morality and general welfare and especially with respect to women because of physical differences and the effect on future generations through the maternal function. ${ }^{71}$ His argument was

that in view of the facts ... set forth and of legislative action extending over a period of more than sixty years in the leading countries of Europe, and in twenty of our States, it cannot be said that the Legislature of Oregon has no reasonable ground for believing that the public health, safety, or welfare did not require a legal limitation on women's work in manufacturing and mechanical establishments and laundries to ten hours in one day. 72

In their decision, delivered by Justice Brewer, the Court noted that "the general right to contract in relation to one's business is part of the liberty of the individual, protected by the Fourteenth Amendment ... yet ... this liberty is not absolute and extending to all contracts." ${ }^{73}$ The basis for their decision was that:

by abundant testimony of the medical fraternity continuance for a long time on her feet at work, repeating this from day to day, tends to injurious effects upon the body, and as healthy mothers are essential to vigorous offspring, the physical well-being of woman becomes an object of public interest and care in order to preserve the strength and vigor of the race.

${ }^{68}$ Oregon, Session Laws, 1903 , p. 148

${ }^{69} 48$ Oregon 252.

${ }^{70}$ The term "Brandeis brief" is even ensconced in legal dictionaries. For a retrospective on MULLER V. OREGON see Ronald K. L. Collins and Jennifer Friesen, "Looking Back on Muller v. Oregon," American Bar Association Journal, 69 (March 1983), pp. 294-98 and (April 1983), pp. 472-77 (note the authors' names are reversed in the second part).

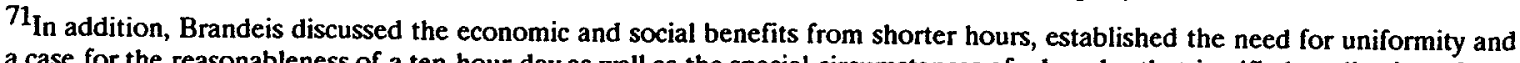
a case for the reasonableness of a ten-hour day as well as the special circumstances of a laundry that justified application of the law to that line of business. See Louis D. Brandeis, Decision of the United States Supreme Court in Curt Muller Vs. State of Oregon .... and Brief for the State of Oregon, (New York: Reprinted by the National Consumers' League, n.d.)

$72_{\text {Ibid., p. } 113 .}$

73208 US 412, p. 5. 
Still again, history discloses the fact that woman has always been dependent upon man. He established his control at the outset by superior physical strength, and this control in various forms, with diminishing intensity, has continued to the present ... her physical structure and a proper discharge of her maternal functions--having in view not merely her own health, but the well-being of the race--justify legislation to protect her from the greed as well as the passion of man. The limitations which this statute imposes upon her contractual powers . . . are not imposed solely for her benefit, but also for the benefit of all. 74

These same protections, however, did not extend to men. Just three years earlier, without the benefit of the Brandeis brief, the Court in the case of LOCHNER V. NEW YORK had outlawed a tenhour law for bakers, ruling that

\begin{abstract}
We think the limit of the police power has been reached and passed in this case. There is, in our judgment, no reasonable foundation for holding this to be necessary or appropriate as a health law to safeguard the public health of the health of individuals who are following the trade of baker... In looking through statistics regarding all trades and occupations it may be true that the trade of a baker does not appear as healthy as some other trades... There must be more than the mere fact of the possible existence of some small amount of unhealthiness to warrant legislature interference with liberty. 75
\end{abstract}

The stunning success of the Brandeis brief led to its use in RICHIE V.WAYMAN ${ }^{76}$ in which the Illinois Supreme Court upheld a 1909 Illinois law establishing a ten-hour day for women in mechanical establishments, factories and laundries. ${ }^{77}$ This law replace a similar one the courts had declared unconstitutional in 1895 without the benefit of the Brandeis brief. ${ }^{78} \mathrm{By}$ the time the brief was presented in RICHIE $V$. WAYMAN it had grown from 112 pages to 610 pages. It was to used again, again and again in Ex parte ANNA HAWLEY, ${ }^{79}$ in MILLER V. WILSON, ${ }^{80}$ and in BOSLEY V. MCLAUGHLIN. 81 And it was recycled and used under counsel of another famous jurist-Felix Frankfurter-in the case of BUNTING V OREGON upholding Oregon's 1913 Ten-Hour law. ${ }^{82}$ By then it had become a two volume, 1,021 page blockbuster. ${ }^{83}$ The decision in BUNTING affirming the state's ten-hour law finally

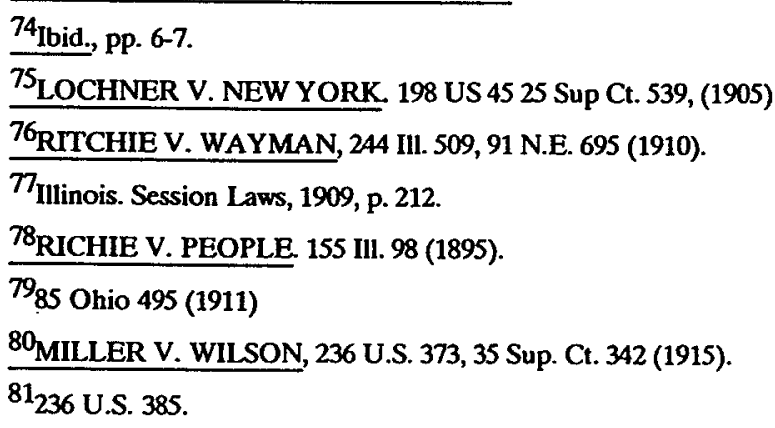

${ }^{82}$ BUNTING V. OREGON, 243 U.S. 246, 37 Sup. Ct. 435 (1917). Frankfurter appeared as Counsel or record for the state of Oregon after Brandeis was nominated as Associate Supreme Court Justice by President Wilson in 1916. The Oregon law declared that "no person"__ that is, man or woman_ could be employed for such long hours or days of service that their health might be injured and that ten hours in one day was consistent with this. See Oregon. Laws of 1913, Chap. 102.

${ }^{83}$ See Felix Frankfurter, The Case for the Shorter Working Day. Supreme Court of the United States. Brief for Defendant in Error, (New York: Reprinted by National Consumer's League). 
settled the issue of shorter hours as a health regulation for men as well as women, reversing the decision in LOCHNER V. NEW YORK.84

It should be noted in passing that health concerns, particularly those concerning women in their maternal function, have recently been ruled insufficient cause for private (as opposed to public) regulation of employment by the U.S. Supreme Court. ${ }^{85}$

\section{HOURS AND CONDITIONS OF WORK IN CALIFORNIA IN 1892}

In 1915, supported by the weighty documentary evidence of an expanded Brandeis brief, the U.S. Supreme Court upheld a 1911 California law establishing an eight-hour day for women in MILLER V. WILSON whereas just twenty years earlier an essentially similar law had been struck down in Illinois. ${ }^{86}$ In the 1890 s, however, there were no real constraints upon adult employment in California although in 1853 the state had passed a law declaring ten hours a legal day. ${ }^{87}$ In 1880 , California workers averaged 9 hours 56 minutes of work per day. ${ }^{88}$ In 1892 , the average work day was 10 hours 11 minutes. ${ }^{89}$ The

\footnotetext{
${ }^{84} 198$ US 45, 28 Sup Ct. 539 (1905)
}

85 INTERNATIONAL UNION, UAW V. JOHNSON CONTROLS, INC The case concerns the "fetal protection" policy of Johnson Controls Inc., a manufacturer of lead-acid automobile batteries. This policy adopted in 1982 bars the employment of fertile women in jobs that bring them into contact with lead dust. The justification is to absolve Johnson Controls from any potential liability for birth defects that may be caused by _or blamed upon_exposure to high concentrations of airborne particles of lead that nevertheless remain within generally accepted safe limits for exposure adopted by the Environmental Protection Agency and by Occupational Safety and Health Administration. Two years after the adoption of this policy, the United Auto Workers filed two class action suits on behalf of its members: One alleged that the company policy of transferring women to other jobs where they would not be exposed to lead dust harmed the chances of men to transfer to those job; the other claimed that women were denied equal access to the high paying —and therefore desirable_— jobs where they would be exposed to lead dust.

An initial decision favoring Johnson Controls was rendered in 1988 by U.S. District Court for the Eastern District of Wisconsin Judge Robert Warren (680 F.Supp. 309), and affirmed by the 7th U.S. Circuit Court of Appeals (886 F.2d 871 (7th Cir. 1989)). However, Justice Robert Staniforth of the state appeals court in Orange County, California ruled in a state suit also brought against the company that "however laudable the concern by business ... for the safety of the unborn, they may not effectuate their goals .... at the expense of the woman's ability to obtain work for which she is otherwise qualified." As a result the policy was held as a violation of Title VII of the Equal Rights Act of 1978 amended to include the Pregnancy Discrimination Act.

In March 1991, the Supreme Court rendered a unanimous decision in the case of INTERNATIONAL UNION, UAW V. JOHNSON CONTROLS, INC. declaring that Johnson Control Inc.'s "fetal protection" policy violated Title VII of the Equal Rights Act of 1978 amended to include the Pregnancy Discrimination Act: "Johnson Controls' professed moral and ethical concerns about the welfare of the next generation do not suffice to establish a bona fide occupational qualification." Furthermore, the Justices argued that "decisions about the welfare of future children must be left to the parents who conceive, bear, support, and raise them." By failing to repeat the state's interest in the welfare of children, this decision appears to reverse the policy enunciated in MULLER v. OREGON (1908):

healthy mothers are essential to vigorous offspring [so that] the physical well-being of woman becomes an object of public interest and care in order to preserve the strength and vigor of the race... differentiated by these matters from the other sex, she is properly placed in a class by herself, and legislation designed for her protection may be sustained, even when like legislation is not necessary for men and could not be sustained.

86 MILLER V. WILSON, 236 U.S. 373, 35 Sup. Ct. 342 (1915). California. Statutes, 1911, p. 437. RICHIE V. PEOPLE. 155 III. 98(1895).

${ }^{87}$ California. Laws of 1853 , Chapter 131, p. 187.

${ }^{88}$ Sample data from the Atack-Bateman sample for California from the 1880 Census of Manufacturing. 
apparent increase in the length of the working day between 1880 and 1892 is, however, misleading. We have argued elsewhere on the basis of independent corroborative evidence that hours of work in 1880 excluded mealtimes. ${ }^{90}$ The estimate for 1892 , though, was made by subtracting quitting time from starting time. It includes the noon-day break for lunch that averaged 44 minutes. Consequently, the actual time spent working in 1892 was only 9 hours 27 minutes.

TABLE 2

Questions Asked by the California Bureau of Labor Statistics of 3,493 Wage-Eamers in that State in 1892

Question Question

Question

1. Industry in which employed

2. Occupation

3. Age

4. Sex

5. Marital status

6. Place of birth

7. Years in the United States

8. Years in Califomia

9. Wages

10. Pay period

11. Annual earnings

12. Time work starts

13. Time work ends

14. Minutes for lunch

15. Number of days lost through sickness

16. Number of days lost through lack of work
Question

17. Number of days lost through other causes

18. Age began working

19. Health when began working

20. Health now

21. Years in present employment

22. Years with present employer

23. Homeowner or renter

24. Number of rooms

25. Amount paid in rent

26. Amount paid for board

27. Amount paid for board and lodgings

28. Number of dependents supported

29. Member of a beneficial organization

30. Member of a labor organization

31. Amount of weekly benefits received

32. Value of other benefits received

Source: California Bureau of Labor Statistics, Survey of 3,493 Wage Earners in California in 1892, Reported in the Fifth Biennial Report of the California Bureau of Labor Statistics for 1893, (Berkeley. Institute of Business and Economic Research, 1990)

The preface to the 1892 survey of wage-earners in California is a little vague on the motivation for the study though it does talk about "this ruinous contention between labor and capital" (presumably a reference to the waves of strikes in the $1880 \mathrm{~s}$ and 1890s) and notes that "the question of increasing or shortening the hours of labor is manifestly one of wages." 91 The inquiry (Table 2) was designed to obtain "reliable information regarding the rates of wages, hours of labor, and other working physical, social, and financial conditions surrounding the wage-workers of the State. ${ }^{192}$ The survey was conducted through personal interviews that "required persistent effort and patient inquiry." ${ }^{93}$ Responses from 3,493

${ }^{89}$ Computed from California Bureau of Labor Statistics, Fifth Biennial Report, op. cit..

90 Jeremy Atack and Fred Bateman, "How Long Was the Workday in 1880?" NBER Working Paper Series on Historical Factors in Long Run Growth, No. 15, August 1990, p. 14.

91 California Bureau of Labor Statistics, Fifth Biennial Report, op. cit., p. 6.

92 Ibid, p. 8.

93 Tbid., p. 10. 
wage-earners were eventually tabulated providing information on thirty-two items though not all questions were answered by everybody. Unfortunately, no details whatsoever are given regarding the criteria for inclusion in the sample.

Wage-earners in the survey were at work between 7 and 16 hours a day (Table 3). These hours included time for lunch, averaging almost 45 minutes but ranging from as little as ten minutes to as long as 90 minutes (Table 4). Assuming that lunch was the only break, the mean number of hours of work was only 9 hours 27 minutes, the mode was $9 \frac{1}{2}$ hours and 81 percent of wage-earners worked ten or fewer hours per day.

Most workers started work early_ more than three-quarters started at 7 a.m. - and quit at 5 p.m. (about two-thirds). Over 80 percent of the sample was male, but women were over-represented relative to their share of the industrial labor-force in 1890. The wage-earners ranged in age from 10 to 76 , but the majority were aged between 16 and 50 and especially in their twenties. Most had begun work by age 15 and so had only been working about 10 to 15 years. Indeed, the mean number of years that the surveyed California wage-earners had worked was 13.96 years. Over three-quarters of all respondents had been working less than twenty years.

\begin{tabular}{lrrr}
$\begin{array}{l}\text { TABLE 3 } \\
\text { Hours at Work for California Wage-Earners in 1892 }\end{array}$ & & Cumulative \\
\hline \hline Hours & Frequency & Percentage & Percentage \\
at Work & & & 0.03 \\
\hline 7 & 1 & 0.03 & 0.39 \\
8 & 11 & 0.36 & 16.47 \\
9 & 498 & 16.09 & 73.71 \\
10 & 1772 & 57.24 & 91.38 \\
11 & 547 & 17.67 & 99.06 \\
12 & 238 & 7.69 & 99.94 \\
13 & 27 & 0.87 & 99.97 \\
14 & 1 & 0.03 & 100.00 \\
16 & 1 & 0.03 & \\
& & & \\
TOTAL & 3096 & & 10.19 \\
\hline
\end{tabular}

Source: California Bureau of Labor Statistics, Survey of 3,493 Wage Earners in California in 1892, Reported in the Fifth Biennial Report of the California Bureau of Labor Statistics for 1893, (Berkeley: Institute of Business and Economic Research, 1990) 


\begin{tabular}{|c|c|c|c|}
\hline $\begin{array}{l}\text { Minutes } \\
\text { for lunch }\end{array}$ & Frequency & Percentage & $\begin{array}{l}\text { Cumulative } \\
\text { Percentage }\end{array}$ \\
\hline $\begin{array}{l}15 \text { or less } \\
16-30 \\
31-45 \\
46-60 \\
61-75 \\
76-90\end{array}$ & $\begin{array}{r}2 \\
1315 \\
517 \\
1184 \\
36 \\
1\end{array}$ & $\begin{array}{r}0.07 \\
43.04 \\
16.92 \\
38.76 \\
1.18 \\
0.03\end{array}$ & $\begin{array}{r}0.07 \\
43.11 \\
60.03 \\
98.79 \\
99.97 \\
100.00\end{array}$ \\
\hline TOTAL & 3055 & & \\
\hline \multicolumn{2}{|c|}{$\begin{array}{l}\text { Average number of minutes for lunch: } \\
\text { Standard deviation of minutes for lunch: }\end{array}$} & $\begin{array}{l}44.05 \\
14.00\end{array}$ & \\
\hline
\end{tabular}

The survey covered workers from 55 industries at the 3- or 4-digit SIC level in 239 different occupations. The most heavily represented industries were breweries, boots and shoes and street cars, each with over 200 respondents. The leading occupations were those of cable car conductor, carpenter, cigar maker, finisher, laborer and sailor, each with over 100 respondents. ${ }^{94}$ The occupations were a mix of white collar and blue collar; those considered healthy and those considered unhealthy; those subject to temperature extremes (e.g. foundryman), dust (e.g. grinder), poisonous fumes (e.g. gilder), and so on as well as those that might be considered desirable (e.g. cable car conductor). Unfortunately, despite the size of the overall sample, many occupation cells were too small to treat them separately. We have therefore sometimes regrouped occupations according to our subjective assessment of the nature of the risks and potential for fatigue posed by each.

Most of the questions called for objective responses. The two questions concerning the state of their health when each wage-earner began work and their health in 1892, however, were answered subjectively. Both are of special interest to us in this paper. People variously described their health as "good," "fair" or "poor" when they began working. They classified their health in 1892 as "good," "fair," "poor," "bad," "average," or "better." What value are such vague, personal, subjective responses? Once, we might have been disinclined to put much faith by such data but recent medical studies have

${ }^{94}$ For a more complete description, see Carter, Ransom, and Sutch, Codebook and User's Manual: Survey of 3,493 Wage Earners in California, op. cit., for a more complete breakdown and description. 
concluded that such opinions are extremely valuable-more valuable, in fact, as a predictor of morbidity and mortality than a complete physical examination..$^{95}$

Because so few wage-earners described the state of their health in 1892 as "average" or "better," we have treated "average" as the same as "good" since at least 80 percent of wage-earners described their health as "good." We rated the health of those whose health was "better" as one rank better than their health was when they began work. Thus those who started out working in "poor" health are deemed to have been in "fair" health in 1892, while those whose health was fair were classified as in "good" health in 1892. Those describing their health as good when they began working and whose health improved are assumed to be still in good health in 1892. Those in "bad" health are assumed to have been in even worse health than those described as in poor health. These workers would probably have been unemployable if they had been forced onto the job market. Cross-tabulation of these subjective health assessments reveals that while the vast majority of wage-earners thought that they were in as good (or poor) health as when they began work, eleven percent thought that their health was worse while only one percent thought that it had improved during their years of work (Table 5).

TABLE 5

The Health of California Wage-Eamers When They Began Working Compared With Their Health in 1892 (percentage of total of 3,184 respondents)

\begin{tabular}{lccr}
\hline & Health When Work Began: & Fair & Poor \\
& & Good & \\
Health in 1892: & & & \\
Good & & 0.53 & 0.31 \\
Fair & 87.06 & 0.75 & 0.25 \\
Poor & 7.41 & 0.16 & 0.22 \\
Bad & 3.08 & 0 & 0.03 \\
\hline
\end{tabular}

Source: California Bureau of Labor Statistics, Survey of 3,493 Wage Earners in California in 1892, Reported in the Fifth Biennial Report of the California Bureau of Labor Statistics for 1893, (Berkeley: Institute of Business and Economic Research, 1990)

The vast majority of workers-those lying along the diagonal in Table 5-described their health in 1892 as the same as it had been when they began work. Only 12 percent thought that it had changed. However, among those who thought that their health had changed during their years of work,

\footnotetext{
95"Mortality Study Lends Weight to Patient's Opinion," New York Times, March 21, 1991, B7 citing a study Dr. Ellen Idler and Dr. Stanislav Kasl in the current issue of Joumal of Gerontology. See also studies by Dr. E. Idler in International Review of Human Psychology (forthcoming) and Dr. E. Idler in American Journal of Public Health (1990). See also European Heart Journal (1988) for study of relationship between feelings of "vital exhaustion" and subsequent heart attacks. Currently, none of these primary sources has been consulted by the authors.
} 
91 percent thought their health was worsened. Health that once was "good" had become only "fair." Some whose health had once been "good," however, found themselves were in "poor" or "bad" health in 1892. Were these changes associated with long hours of work, limited rest periods, and unhealthy conditions of work?

The figures in Table 5, however, almost certainly understate the true extent of ill-health. There is an inherent selection bias in the sample. Those in bad or worsening health were much more likely to have exited this labor force_-voluntarily or involuntarily_through death, retirement, disability, termination or career switch. So long as the supply of labor was elastic and in an era when employers were not held legally responsible for the possible adverse effects of work conditions on employee health, there was little incentive to retain the sick and impaired who might infect or demoralize the rest of the workforce. We therefore believe that our findings err on the side of conservatism. They are biased against a finding of worsening health associated with long hours and fatigue-inducing work conditions.

The other measure of health in the 1892 California survey is the number of days of work lost by each worker on account of illness during the preceding year. Unfortunately, the interviewers did not distinguish between those who lost no days through illness and those who declined to answer. There are no respondents who reported zero days lost through sickness. Instead, there are 2,557 (73 percent) blanks for this question. If blanks are treated as zeroes, then the mean number of days lost through sickness by California wage-earners in 1892 was 6.86 days, or about 2 percent of the possible working days per year. This seems implausibly low even allowing for sample bias against the inclusion of unhealthy workers. For example, it is only about half the amount of time lost through sickness by workers on a 54-hour work week (that is somewhat less than being worked by California wage-earners in 1892) in British Ordinance factories during the First World War when there was considerable patriotic pressure to be at work. ${ }^{96}$ On the other hand, ignoring the problem results in an implausibly high estimate of average number of days lost through sickness_- 25.59 days, or one month's work, per year-though this, presumably, is a good estimate of the average number of days lost by those workers who became sick.

This is a serious problem. We have dealt with it as follows: where respondents reported some days lost through lack of work or other causes, we have assumed that a blank for days lost through sickness is really a zero. Where days lost from whatever source were all blank, we assume that the questions were

\footnotetext{
${ }^{96}$ Great Britain. Medical Research Committee, "Adaptation of Output to Altered Hours of Work," op. cit., p. 31.
} 
not answered. ${ }^{97}$ This still probably leaves an upward bias in our estimate of the number of days lost since some of those surveyed presumably lost no days through lack of work or other cause either although no zeroes were recorded. The effect of this adjustment is to "create" 1,050 workers who lost no days during the year through ill-health. These make up somewhat more than half the total number of workers for whom we have estimates of days lost through sickness. Is the adjustment plausible? With the addition of these healthy workers, the average number of days lost through sickness is $\mathbf{1 2 . 0 6}$ days_ two working weeks per year_ or about 3.9 percent of the possible working days per year. This is fairly close to the experiences of workers during World War I on a 54-hour work week. ${ }^{98}$

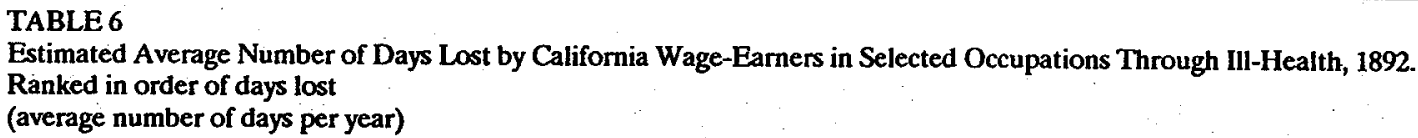

\begin{tabular}{lcr}
\hline \hline Occupation & Days Lost & Number of wage-earners \\
\hline Ironer (laundry) & 35.00 & 23 \\
Brewery workers & 33.79 & 28 \\
Harness-maker & 25.12 & 43 \\
Cooper & 21.08 & 24 \\
Basket makers & 20.27 & 15 \\
Polisher & 16.38 & 21 \\
Fitter & 15.10 & 20 \\
Tinsmith & 14.81 & 16 \\
Pressman & 13.89 & 19 \\
Plasterer & 13.24 & 21 \\
Tanner & 13.07 & 15 \\
Brass worker & 12.27 & 11 \\
Cigar maker & 11.92 & 87 \\
Tailoress & 11.91 & 34 \\
Machinist & 10.48 & 42 \\
Laborer & 10.43 & 58 \\
Painter & 10.16 & 19 \\
Carpenter & 10.01 & 68 \\
Stonecutter & 8.91 & 11 \\
Tailor & 8.38 & 78 \\
Cable car conductor & 8.24 & 94 \\
Printer & 7.90 & 10 \\
Bookbinder & 7.73 & 15 \\
Furniture worker & 6.88 & 24 \\
Mason & 6.70 & 30 \\
Salesclerk & 4.77 & 13 \\
Baker & 3.13 & 16 \\
& & \\
\hline
\end{tabular}

Source: California Bureau of Labor Statistics, Survey of 3,493 Wage Eamers in California in 1892, Reported in the Fifth Biennial Report of the California Bureau of Labor Statistics for 1893, (Berkeley. Institute of Business and Economic Research, 1990)

${ }^{97}$ This procedure was suggested to us by Susan Carter. We thank her for her suggestion.

98 Ibid. 
Our best estimates of the average number of days lost through ill-health among California wageearners by occupation are shown in Table 6. Ironers-a predominantly female occupation-averaged more lost days through sickness than any other occupational group in California. Interestingly, and perhaps significantly, laundries were singled-out in the Oregon hours law and figured in the case of MULLER V. OREGON. Indeed the Brandeis brief quotes a British M.D. in testimony before Parliament that:

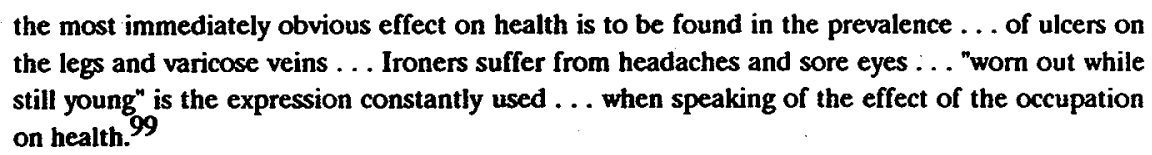

Other unhealthy occupations, measured by days lost through sickness in 1892 , were brewing, coopering, and polishing activities with known and well-documented health hazards-as well as two unexpectedly unhealthy and unexplained occupations, harness- and basket-making. Bakers and sales clerks lost the fewest days on account of ill-health. The finding with respect to bakers is particularly surprising since this occupation, along with brickyard workers, was singled out by the New York state legislature for special restrictions on hours as a public health regulation, ${ }^{100}$ but may explain why the U.S. Supreme Court rejected this claim in LOCHNER V. NEW YORK. ${ }^{101}$ Arguably, of course, from a public health standpoint one wants those who prepare comestibles to be more than fairly healthy, especially so far as communicable diseases are concerned!

Organized by industry, the most healthy industries in which to work were baking, basket making, corset manufacture, flour milling, artificial flowers, glassmaking notions and fancy goods, stonecutting (cf. Figure 2!), and the telegraph industry where workers generally lost less than one week per year through sickness. The least health were brewing and coopering where workers lost at least four weeks per year through sickness.

Alone, these statistics give us little sense of how typical the health experiences of wage-earners in California might have been at this time. There are, however, extensive records for other countries. ${ }^{102}$ The best estimates for morbidity during the late nineteenth century seem to be from the Local Sick

\footnotetext{
99 Brandeis, Decision of the United States Supreme Court in Curt Muller Vs. State of Oregon, op. cit., p. 108-9.

109 New York. Laws of 1896, Chapter 789, Vol. I amending Chapter 691 of 1893.

$101_{198}$ U.S. 45 (1905), op. cit.

${ }^{102}$ See, for example, James C. Riley, "Working Health Time: A Comparison of Preindustrial, Industrial, and Postindustrial Experience in Life and Health," Explorations in Economic History, 28 2(April 1991), pp. 169-91.
} 
Benefit Society of Leipzig, Germany (Table 7). ${ }^{103}$ These represent the experiences of about 141,000 workers between 1887 and 1904 and so cover the same period as the California survey. They are a yardstick for comparison with the experiences of California wage-earners in 1892 . The least healthy occupations for men in Leipzig were occupations such as marble- and stone-cutting, machinists, grinders, and brickworkers who were constantly exposed to dust and iron and steel workers, brewery workers, and laundry workers who worked under extremes of temperature and humidity. Days lost through sickness were least among white-collar workers such as clerks. In most occupations, women seem to have lost more days through sickness than men, though whether because of their own ill-health or that of dependents is unknown.

\begin{tabular}{|c|c|c|}
\hline Occupation & Men & Women \\
\hline Marble and stone cutters & 12.94 & \\
\hline Iron and steel workers & 12.56 & - \\
\hline Grinders & 12.15 & 14.56 \\
\hline Iron founders and machinists & 11.89 & 16.66 \\
\hline Coopers & 11.22 & - \\
\hline Brickworkers & 11.18 & - \\
\hline Brewery workers & 11.06 & - \\
\hline Tanners & 10.49 & - \\
\hline Painters & 10.17 & - \\
\hline Laundry workers & 9.76 & 9.66 \\
\hline Pottery workers & 9.57 & - \\
\hline Basket Makers & 9.47 & - \\
\hline Chemical workers & 9.47 & 13.42 \\
\hline Cigar and Tobacco & 9.09 & 11.58 \\
\hline Bookbinders & 9.04 & 12.38 \\
\hline Leather workers & 8.78 & - \\
\hline Carpenters & 8.77 & - \\
\hline Street railroad employees & 8.70 & - \\
\hline Printers and pressmen & 8.51 & 11.30 \\
\hline Tinware & 8.24 & - \\
\hline Furniture workers & 8.10 & - \\
\hline Glaziers & 8.04 & - \\
\hline Masons & 7.77 & - \\
\hline Brass workers & 7.61 & - \\
\hline Plasterers & 7.38 & - \\
\hline Tailors & 7.15 & 8.84 \\
\hline Boots and shoes & 6.42 & 9.32 \\
\hline Bakers & 4.97 & 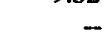 \\
\hline Clerks & 4.04 & 7.33 \\
\hline
\end{tabular}

Sources: George M. Kober and William C. Hanson (eds.), Diseases of Occupation and Vocational Hygiene, (Philadelphia: P. Blakiston's Son \& Co., 1916), pp. 749-61.

${ }^{103}$ Kober and Hanson, Diseases of Occupation, op. cit., pp. 749-61. 
Those in the most unhealthy occupations in California lost many more days per year in 1892 than workers in Germany at about the same time. The number of days lost in the healthiest occupations, however, were similar. More significantly the rankings of occupations based upon days lost are similar for workers in California and Germany. Least healthy were occupations in brewing, coopering, polishing and the like. Health, measured by days lost, was best among bakers and salesclerks. Tailors lost about the same number of days per year (and tailoresses lost more than their male counterparts); street railroad employees look a lot like San Francisco cable car conductors in terms of days lost and so on. 104 At the same time, there are some notable differences between occupational ranks by health between California and Germany. Ironers were not separately identified in the Liepzig data but laundries do not seem to have been the very unhealthy places that they were in California. Similarly, plasterers in Germany enjoyed fairly good health; those in America were sick quite frequently. So too were brass workers. ${ }^{105}$ Such differences notwithstanding, we feel the degree of correspondence is remarkably good, especially considering the small number of observations for some occupations. These results give us considerable confidence in our estimating procedures.

\section{OCCUPATIONS, HOURS, FATIGUE AND ILL-HEALTH IN CALIFORNIA IN 1892}

We have used the data from the survey of California wage earners to estimate the importance of various factors in determining whether or not a worker's health was worse in 1892 than when the worker entered the labor force. However, Vernon has remarked that sickness is greatly influenced by other factors than fatigue, many of which we cannot observe such as heredity, nutrition, the health of one's family and co-workers and the home environment. ${ }^{106}$ We have tried to control for as many of these as possible. Nevertheless, our model (Figure 5) suggests that hours of work and the -nature of the job should affect a person's health. And as we shall see, this appears to be the case.

\footnotetext{
${ }^{104}$ Interestingly, some of the occupations that had inspired protective legislation elsewhere such as baker (limits on hours in New York) or salesclerk (seats) were apparently among the most healthy occupations in California in 1892 as judged by the average number of daysi lost per worker through sickness.

${ }^{105}$ These differences may reflect differences in government regulations regarding occupational health and safety, differences in technique or a differential emphasis upon cleanliness and sanitation. For example, in 1909-10 mortality from tuberculosis among grinders in Solingen, the center of the German cutlery industry, was 4.37 per 1,000 compared with 15.80 per 1,000 in Sheffield, center of the English cutlery trade, between 1901 and 1909. In Solingen the grindstones were guarded, ran only under a stream of water and rotated towards the operator whereas in Sheffield the practice was entirely the reverse. In addition, the Germans placed cuspidors where needed and emphasized the need to prevent "promiscuous expectoration." See Kober and Hanson, Diseases of Occupation, op. cit., p. 428-9.

${ }^{106}$ Vernon, Industrial Fatigue, op. cit., p. 7.
} 
The survey provides direct evidence on hours of work. We have measured these as the time between when work began each day and when it ended less the lunch break. Assessing the nature of the job, however, proved more difficult. We have used the occupations and industries listed in the survey, our reading of the literature regarding occupational hazards and our subjective assessments to classify occupations into those involving exposure to harmful dust, those involving exposure to heat, those demanding extraordinary physical exertions, those with exposure to toxic or harmful substances, and those that were monotonous or involved repetitive motions and whose pace was set by machine. For example, the job of stonecutter or grinder were classified as dusty; foundrymen, firemen and ironers were exposed to heat; blacksmithing and coopering were classified as physically arduous; and compositors, lead burners and varnishers risked poisoning. Some occupations, such as plasterer (physical, dusty work) or caster (hot, dusty, physical work with exposure to noxious and potentially toxic gases) involved more than one potential health hazard and were assigned to each appropriate category. At the opposite end of the spectrum, we classified some jobs as nice, genteel, "cushy" jobs_— jobs such as cable car conductor, salesclerk, or manager.

Our model suggests that exposure_-especially prolonged exposure-to occupational health hazards and long hours of work are a factor in the breakdown of health. In addition we have controlled for a variety of personal, home and work-related attributes that might also affect health such as age, sex, marital status, wealth, and possible immunity to diseases. We have expectations about how these various other factors might affect health:

1. Age: We expect that health improves during the prime of life (the twenties and early thirties) as a result of survival and with immunity from many childhood diseases but worsens with middle age.

2. Sex: Women use more sick days than men. In part this may reflect social norms that expect women to nurse other family members back to health, but women also visit the doctor more often. Many have less physical strength and may be more susceptible to toxins because of their lower body weight. We therefore expect that working women exposed to long hours and unhealthy working 
conditions are more likely than men to have experienced a worsening in their health, ceteris paribus.

3. Marital Status: Numerous studies have shown that married men are emotionally and physically healthier. The direction of causation, however, is unclear. The same studies suggest that married women are less likely to be as emotionally and physically healthy as their unmarried sisters. Ideally we would therefore like to control for both marital status and sex but there were very few married female wage-earners in the sample. The sign is ambiguous. The support of a partner should improve health. The need to support dependents, however, may increase labor market commitment even in the face of failing health.

4. Number of dependents: The more people relying upon a fruits of one's labor, the greater the degree of labor market commitment even in the face of failing health

5. Native-versus Foreign-born: To the extent that there exist distinct disease environments and genetic predispositions, we expect native-born to be healthier than foreign-born. This should be reinforced by wealth differentials.

6. Years in the United States and years in California: These variables should also capture the effects of "seasoning" and climatization to differing disease pools. For the native-born, years in the United States is the same as age.

7. Years in occupation: To the extent that exposure to certain occupational health risks exert a cumulative effect it should show up in this variable.

8. Years with employer: The effect is ambiguous. The longer one has been with an employer, the longer one's exposure to specific 
health hazards but longer-term employees are more likely to have been promoted to more desireable jobs with better working conditions.

9. Frequency of wage payment: This is a proxy for the nature of the implicit labor contract. The shorter the pay period, the less the employer's commitment to a worker and hence the less their interest in a particular worker's health.

10. Annual earnings: This variable is a proxy for the wealth of the wage-earner. We expect that wealthier people will tend to be healthier either as a result of better health care or a healthier environment. However, we also note that healthier people are more productive and thus can presumably earn and accumulate more.

11. Age began work: We expect that those entering the labor market during their childhood and youth would be less well developed and less healthy than those who started work after they were fully grown. This argument was frequently used to justify child labor laws.

We have used these variables in a logit regression to explain worsening health in the labor force. The results for those workers in occupations judged to be hot, dusty, repetitive/machine-driven, physically exhausting or involving exposure to toxic chemicals are shown in Table 8. The equation incorporates stong priors in the specification regarding the relationship between health and job characteristics and the various pathways through which job characteristics affected health. In some cases, such as speedy and repetitive work, we believe the effects are short-term and immediate. In others, such as exposure to dust and toxins, the adverse health effects are seen only after prolonged exposure perhaps lasting many years.

However, the precise specification of these relationships between occupational health hazards and changes in health since starting work-for example, the use of a cubed rather than a squared term-was the result of systematic experimentation to maximizing the proportion of correct 
predictions for those workers in worse health consistent with our priors and with medical/occupational health literature.

As we have already noted, relatively few workers reported worsening health during the course of their working lives. We believe that this reflects sample bias rather than any intrinsic healthiness in the late nineteenth century workplace. The sample is censored in that we believe those in worsening health are under-reported because some_- perhaps even many_-dropped out of the survey population. Unfortunately the sample is neither clearly censored nor truncated. ${ }^{107}$ There were workers in "good," "fair," and "poor" health and whose health worsened a little or a lot during their working lives (which ranged from 0 to 58 years) up to the time of the sample. There does not appear to be any arbitrary assignment of health status (except perhaps to "good"). No group is clearly missing. Furthermore, we have no information about the sampling procedure that will permit us to estimate a sample selection model after Heckman. ${ }^{108}$ Instead, we must simply note that our estimates are biased and we assert that this bias is towards zero - that is to a finding of no health effects where such do indeed exist. The bias in the sample may also explain why some of the simpler specifications that we tried for the effects of occupational health hazards on health appeared, over some ranges, to be associated with improving, rather than worsening health. Workers sorted among jobs. Those workers adversely affected early on by some occupational hazard probably quit.

A positive logit coefficient implies, ceteris paribus, a change in health for the worse with that particular characteristic. Thus, for example, longer hours of work are associated with worsening health. However, care is required interpreting the impact of jobs characteristics because of the interaction terms that we have introduced to model our priors about the relationship of these characteristics to health. For example, we believe that it is not exposure to dust that matters but how many years one is exposed to dust concentrations and the effects are cumulative as the lung tissue becomes scarred. Similarly, one might experience an immediate reaction to toxic chemicals but if not then it takes years of exposure before health is affected. The problem of interpretation is compounded because under our classification many of the jobs that demanded physical exertion were also classified as involving exposure to heat (correlation $=0.28$ ) and those that were dusty frequently involved exposure to toxic chemicals (correlation $=0.19$ ). Conversely, those jobs that we classified involving repetitive and speedy

${ }^{107}$ See, for example, G. S. Maddala, Limited and Qualitative Dependent Variables in Econometrics, (Cambridge University Press, 1983).

${ }^{108}$ See James J. Heckman, "Sample Selection Bias as a Specification Error," Econometrica, 47, 1(January 1979), pp. $153-62$. 
motions were rarely classified as demanding physical exertion (correlation $=-0.27$ ) or stamina in the face of heat (correlation $=-0.42$ )

\begin{tabular}{|c|c|c|c|c|c|}
\hline \multirow{2}{*}{$\begin{array}{l}\text { Variable } \\
\text { Hours of work }\end{array}$} & \multirow{2}{*}{$\begin{array}{l}\text { Logit } \\
\text { cient } \\
\frac{0.493391}{(2.10)}\end{array}$} & \multirow{2}{*}{$\begin{array}{l}\text { Mean } \\
9.330\end{array}$} & \multirow{2}{*}{$\begin{array}{ll}\text { Variable } & \text { Coeff } \\
\text { Marital status (Married }=1 \text { ) }\end{array}$} & $\begin{array}{l}\text { Logit } \\
\text { cient }\end{array}$ & \multirow{2}{*}{$\begin{array}{l}\text { Mean } \\
0.324\end{array}$} \\
\hline & & & & $\begin{array}{l}-0.008927 \\
(-0.03)\end{array}$ & \\
\hline HOT*hours of work squared & $\frac{0.143386}{(2.58)}$ & 24.240 & Number of dependents & $\begin{array}{l}0.125492 \\
(1.56)\end{array}$ & 1.130 \\
\hline HOT ${ }^{\star}$ hours of work cubed & $\frac{-0.014462}{(-2.49)}$ & 231.198 & Native-born (Native-born $=1$ ) & $\begin{array}{l}-0.527797 \\
(-1.09)\end{array}$ & 0.524 \\
\hline TOXIC $($ Yes $=1)$ & $\frac{-0.735391}{(-1.69)}$ & 0.208 & Paid daily $($ Yes $=1)$ & $\frac{1.854116}{(2.11)}$ & 0.362 \\
\hline TOXIC years of exposure squared & 0.001034 & 37.466 & Paid weekly $($ Yes $=1)$ & $\frac{2.083739}{(2.45)}$ & 0.546 \\
\hline DUST*years of exposure & $(-0.186609$ & 0.485 & Years in California & $\frac{-0.063706}{(-2.96)}$ & 15.994 \\
\hline DUST"years of exposure cubed & $\frac{0.000001}{(2.01)}$ & 87969.640 & Years in the United States & $\frac{0.052105}{(2.21)}$ & 19.270 \\
\hline PHYSICAL*age & $\frac{-0.026088}{(-2.37)}$ & 7.288 & Years in occupation & $\frac{0.063272}{(2.00)}$ & 4.120 \\
\hline SPEED $($ Yes $=1)$ & $\begin{array}{l}4.838484 \\
(1.31)\end{array}$ & 0.345 & Years with employer & $\begin{array}{l}0.001995 \\
(0.07)\end{array}$ & 9.472 \\
\hline SPEED*hours of work & $\begin{array}{l}-0.562144 \\
(-1.43)\end{array}$ & 3.167 & Ever switched jobs? (Yes = 1) & $\begin{array}{l}0.396684 \\
(1.30)\end{array}$ & 0.550 \\
\hline Age & $\frac{0.149390}{(1.81)}$ & 28.345 & Age when started working & $\begin{array}{l}-0.059092 \\
(-1.26)\end{array}$ & 15.189 \\
\hline Age squared & $\frac{-0.002265}{(-2.09)}$ & 914.940 & Annual earnings & $\frac{-0.001929}{(-2.99)}$ & 623.371 \\
\hline Sex $($ Male $=1)$ & $\begin{array}{l}-0.119500 \\
(-0.29)\end{array}$ & 0.772 & Constant & $\frac{-8.737175}{(-3.17)}$ & 1.000 \\
\hline $\begin{array}{l}\text { Log-likelihood ratio } \\
\text { Number of observations }\end{array}$ & $\begin{array}{l}-254.74073 \\
777\end{array}$ & & $\begin{array}{l}\text { Chi-squared ( } 25 \text { ) } \\
\text { Mean value of dependent variab }\end{array}$ & $\begin{array}{l}98.48 \\
\text { e } 0.132561\end{array}$ & \\
\hline
\end{tabular}

Comparison of Outcomes and Probabilities

\begin{tabular}{lrrl}
\hline Outcome & Pr $<.5$ & Pr $>=.5$ & Total \\
\hline $\begin{array}{lrrl}\text { Failure } \\
\text { Success }\end{array}$ & 668 & 6 & 674 \\
\hline Total & 91 & 12 & 103 \\
\hline
\end{tabular}

Source: California Bureau of Labor Statistics, Survey of 3,493 Wage Earners in California in 1892, Reported in the Fifth Biennial Report of the California Bureau of Labor Statistics for 1893, (Berkeley. Institute of Business and Economic Research, 1990) 
The data do not reveal a statistically significant relationship between health and those occupations where machines set the pace. This may reflect the nature of the sample or it may reflect gross errors in our assignment of occupations according to occupational hazards. The data do, however, provide clear evidence of systematic statistical relationships between long hours of work in occupations involving exposure to heat and changes in health and between years of exposure to toxins and dust and changes in health. The longer the daily exposure and the longer the duration of the exposure to the insult to health the greater the probability of worsening health. Wage earners in jobs that demanded strenuous physical exertion, however, generally appeared to have flourished. We had expected that their health would have declined as they aged in these physically-demanding jobs. The reverse appears to be the case. This finding probably reflects sorting in which only the fittest survived in these job.

As shown by the table of outcomes and probabilities at the bottom of Table 8 , this logit regression correctly predicts the change in health of over 87 percent of the wage-earners between their entry into the labor market and 1892 in those occupations that involved exposure to dust, toxic chemicals, high temperatures, extreme physical exertion or speedy, repetitive motions. However, this statistic alone is somewhat misleading. The equation does an excellent job of predicting those whose health would be unchanged as a result of work ( 99 percent correct), but correctly predicts the worsening health of less than twelve percent of those who health worsened during the period of their employment. The results are therefore not as decisive as we might have hoped. Nevertheless, given the selection bias against workers in worse health remaining a part of the labor force and the wide variety of unobserved determinants of a person's health, we think that the results are surprisingly good.

The impact of the different factors upon an individual's health status are generally consistent with our expectations (Table 9). Consider the case of 30 year-old, single American male-with one dependent earning $\$ 600$ a year and paid by the day who started work at age 15 , moved to California at age 20 and works 10 hours a day in dusty job that he has had for 5 years. We estimate the probability that such an individual was in worse health in 1892 than when he began working at 0.354 . If this individual worked 11 hours a day instead of 10 , we estimate that the probability that his health would be worse would be 0.474; if he had worked at the job for 10 years instead of 5 , the probability that his health would be worse is estimated to be $\mathbf{0 . 4 3 0}$. Under the same circumstances, the probability of worse health for a woman would have been about 8 percent higher- 0.383 versus 0.354 . An immigrant was much more likely to find himself in worse health; so too were those earning less per year or who began work earlier in life. The evidence also suggests a life cycle pattern in health. The probability of worsening health increased 
up to about age 33 and declined thereafter. We take this as further evidence of sorting — only the relatively fit and healthy remained in the surveyed workforce of California wage-earners.

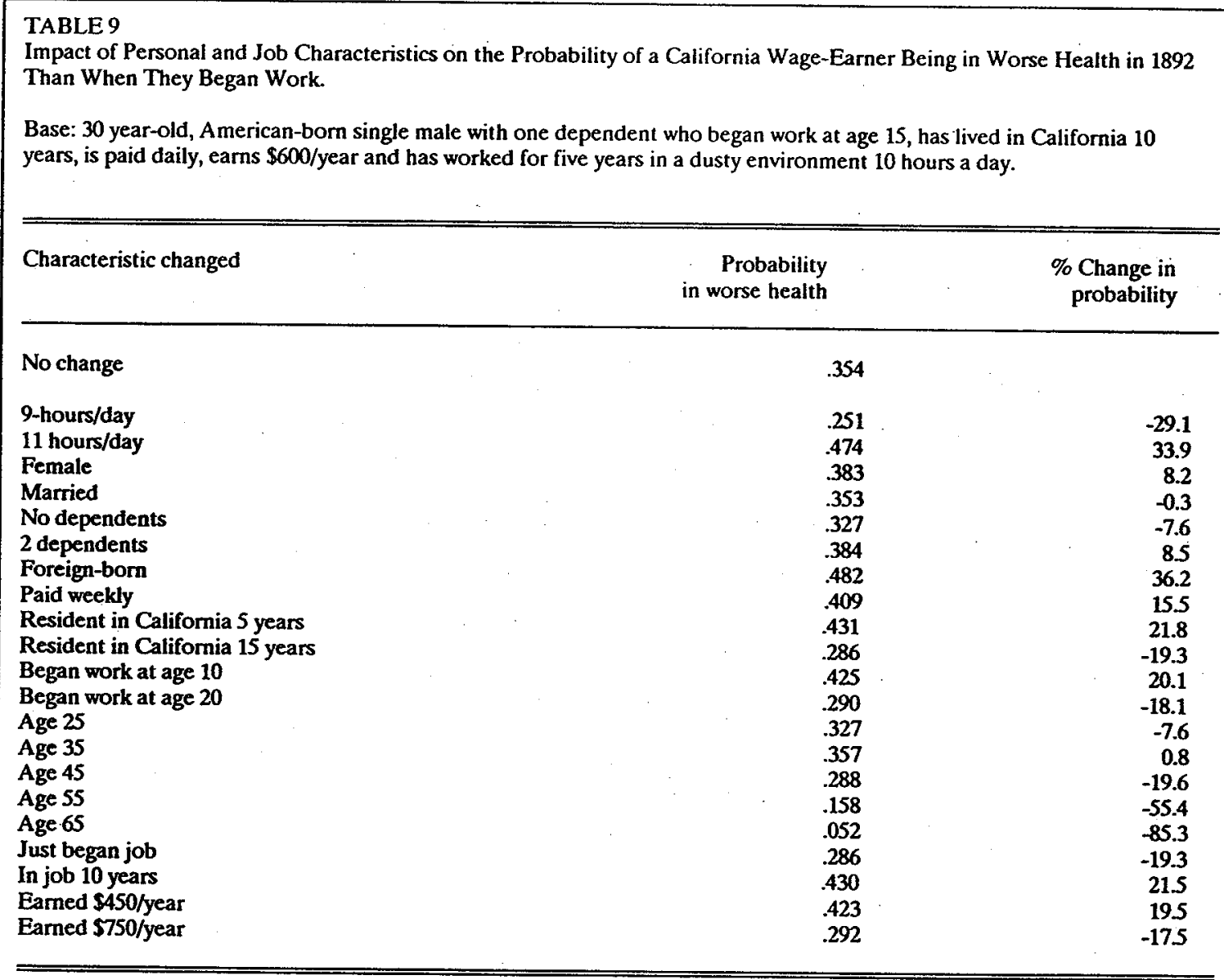

Source: Calculated from Table 8.

The parameter estimates in Table 8 show statistically significant relationships between hours of work and the change in the state of an individual's health during their working years (Figure 6). These effects were also sometimes quite large. For example, the probability of worsening health for a worker working only 7 hour a day (the minimum in the sample) was only 0.084 while the same worker working 16 hours a day (the maximum in the sample) was almost certain (probability 0.886) to experience worsening health. The health of those working very short hours even under adverse conditions seems to have been affected relatively little but those working long hours suffered from rapidly worsening health, particularly in dusty occupations or those involving exposure to toxic chemicals. Even where the independent effect seem relatively small as in the case of long-term exposure to toxic chemicals, the probability of worsening health for someone working ten hours a day is more than one-third higher if 
they have been exposed for twenty years than if they had been exposed for less than one year. Worsening health in those occupations associated with exposure to high temperatures increased sharply with long hours up to about $\mathbf{1 0}$ hours and decreased for those working longer hours. We suspect that women, particularly laundry workers, worked ten or fewer hours a day whereas men in coopering, brass and iron furnaces and the like worked ten or more hours a day, though we do not intend to dismiss the possibility that the differences in probability of worsening health reflect job characteristics more than the characteristics of the workforce.

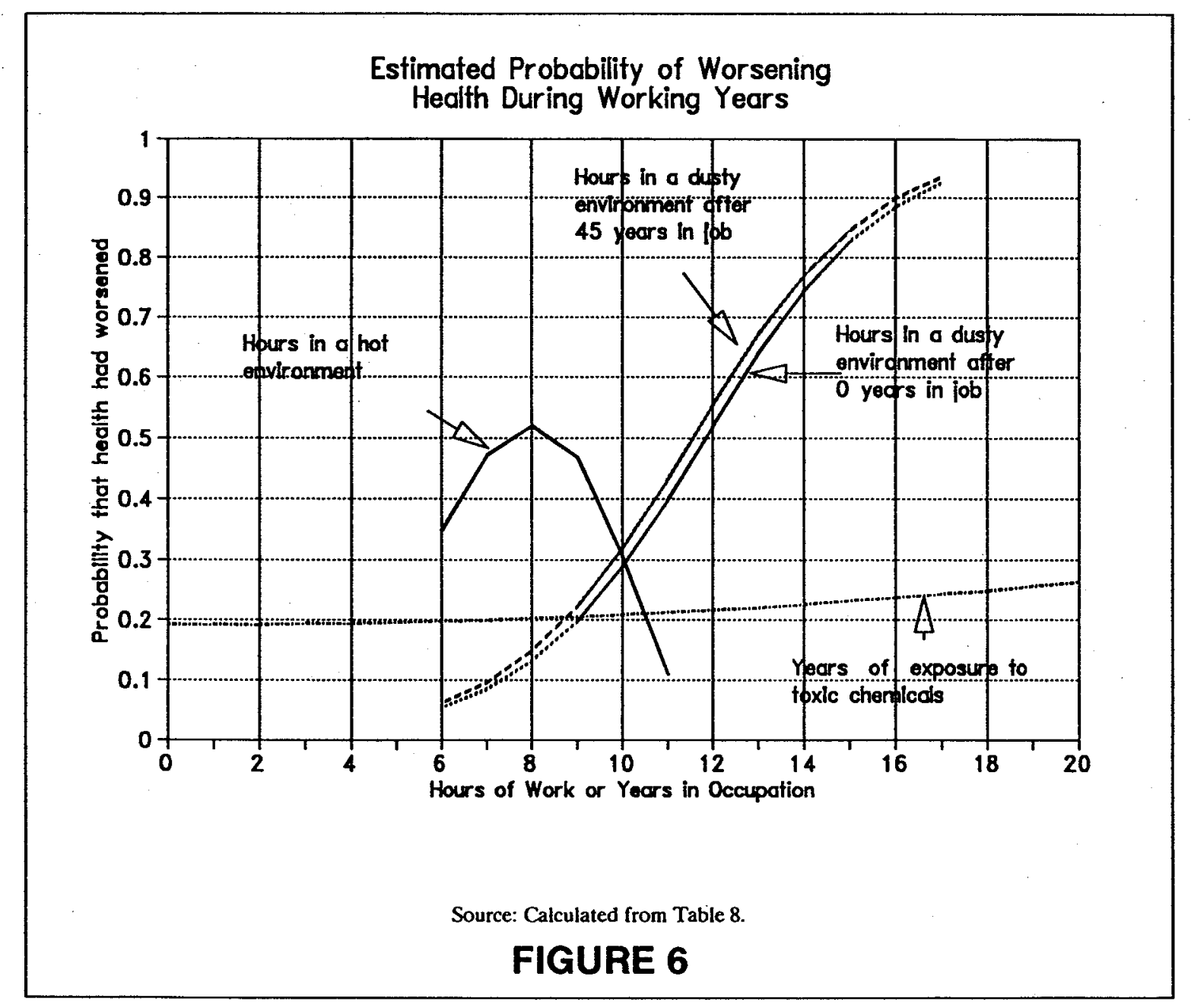

Whereas relatively few Californian wage-earners reported worsening health since starting work, over 900 reported one or more days absence through sickness during the preceding year and we have inferred that at least a thousand more lost no days through ill-health. We have used these data in conjunction with the information on worker and job characteristics to investigate whether hours of work 
and the nature of the job had any impact upon days of work lost through sickness each year. They did (Table 10).

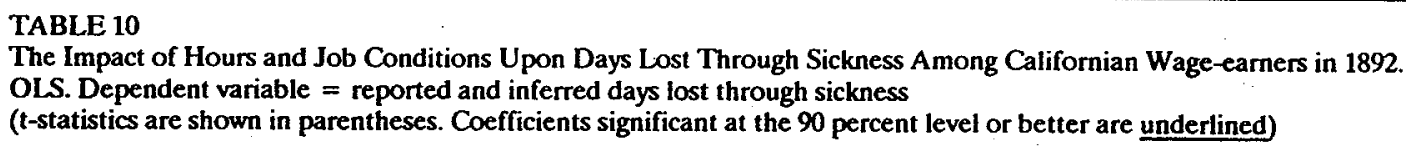

The Impact of Hours and Job Conditions Upon Days Lost Through Sickness Among Californian Wage-eamers in 1892. OLS. Dependent variable $=$ reported and inferred days lost through sickness ( $t$-statistics are shown in parentheses. Coefficients significant at the 90 percent level or better are underlined)

\begin{tabular}{|c|c|c|c|c|}
\hline Variable & ient & Standard Error & t-statistic & Mean \\
\hline Days sick & & & & 12.4065 \\
\hline $\begin{array}{l}\text { Hours at work per day } \\
\text { Age } \\
\text { Age-squared } \\
\text { Sex (Male = 1) } \\
\text { Marital Status (Married = 1) } \\
\text { Native-born (Native-born = } 1 \\
\text { Years with employer } \\
\text { Age at which began working } \\
\text { Number of dependents } \\
\text { Member of beneficial society (Yes = 1) } \\
\text { Member of a union (Yes = 1) } \\
\text { Exposure to heat"hours of work } \\
\text { Exposure to dust "years of exposure } \\
\text { Exposure to toxic substances"years of exposure } \\
\text { Pysically exhausting job*age } \\
\text { Repetitive/speedy job"hours of work } \\
\text { Ever-switched jobs }\end{array}$ & $\begin{array}{r}\frac{2.0798}{0.3373} \\
-0.0040 \\
\frac{-8.8953}{2.1259} \\
\frac{-3.3646}{-0.2061} \\
-0.4445 \\
0.0491 \\
-1.4822 \\
1.7865 \\
0.9952 \\
-0.0790 \\
-0.1269 \\
0.1589 \\
0.3086 \\
-2.1619\end{array}$ & $\begin{array}{l}0.6941 \\
0.4464 \\
0.0057 \\
2.9785 \\
2.4598 \\
1.8438 \\
0.2288 \\
0.2562 \\
0.6408 \\
2.0159 \\
2.2248 \\
0.2917 \\
0.1240 \\
0.1927 \\
0.0692 \\
0.2328 \\
2.0426\end{array}$ & $\begin{array}{r}2.997 \\
0.756 \\
-0.695 \\
-2.987 \\
0.864 \\
-1.825 \\
-0.901 \\
-1.735 \\
0.077 \\
-0.735 \\
0.803 \\
3.411 \\
-0.637 \\
-0.659 \\
2.297 \\
1.326 \\
-1.058\end{array}$ & $\begin{array}{r}10.3057 \\
30.6237 \\
1047.8820 \\
0.8589 \\
0.3774 \\
0.5610 \\
3.5498 \\
15.1579 \\
1.1848 \\
0.4446 \\
0.3113 \\
1.1501 \\
4.2240 \\
1.3315 \\
6.3393 \\
2.6429 \\
0.6842\end{array}$ \\
\hline $\begin{array}{l}\text { Adjusted R2 } \\
\text { F-ratio }\end{array}$ & $\begin{array}{l}0.2049 \\
14.54\end{array}$ & Numb & r of observations & 893 \\
\hline
\end{tabular}

As efficiency experts found during World War I and World War II, long hours at work were associated with more days absence from work from sickness. For each additional hour worked per day, between two days a year extra were lost. The increase in time lost during the year, however, would fail to offset the cumulative time gained from longer hours. One hour extra per day would increase labor supplied by perhaps $290-300$ hours during the course of a normal working year. Employers might therefore have viewed longer hours as a worthwhile solution to a shortage of labor unless the decline in average productivity was sufficient to offset any marginal gain during these additional working hours. Hot and physically exhausting tasks such as those in a laundry, a steel mill or a barrel-making plant were also associated with more days lost per year through sickness. For example, women in laundries working 10 hours a day are predicted to have lost at least 18 days more per year ( 8.9 days extra for being female plus 9.95 days for the 10 hours per day of work under hot conditions) than a male working on, say, the cable cars. Similarly, a 55 year-old cooper is predicted to have lost about five and a half days more per 
year than a 20 year-old in the same job because of the rigors of the job. The coefficients on repetitive or speedy jobs and those involving exposure to dust and toxic substances were not statistically significant although the effect of speedy and repetitive work was fairly large_a worker in such a job might lose 3 days more through sickness than someone in a less demanding job. Unfortunately we don't know whether the magnitude of these coefficients reflects failings in our classification of jobs, employer efforts to deal with the problem of occupation health, or that these jobs were just not that unpleasant.

Workers also lost time through sickness for reasons other than long hours in unhealthy occupations. Days lost through illness tended to increase with age until the early forties. It declined thereafter. We infer from this that the chronically-ill left the labor market through voluntarily or involuntary early retirement or death. Women lost significantly more days per year through sickness__almost nine more working days a year__than men. It does not appear that this can be explained by social customs that required that women (and not men) care for sick dependents. The amount of time lost through sickness did, however, increase with the number of dependents although the effect was small. The native-born consistently lost fewer days through sickness than immigrants. Although the coefficient was never statistically significant, we found it interesting that wage-earners who participated in a beneficial society, which partially compensated them for lost wages the event that illhealth preventing their working, consistently lost fewer days through sickness. Perhaps the societies vetted claims for compensation or only admitted members who were healthy.

\section{CONCLUSION}

If we were to rely solely upon the evidence from the 1892 survey of California wage-earners, we might be less than completely convinced that long hours of work each day in hot and poorly ventilated workshops performing physically or mentally exhausting work at a pace set by inanimate machines was bad for employee health. However, it does appear that worsening health and increasing numbers of days lost through sickness are systematically related to these factors in the California data even though contemporaries might not have been able to document them as we have done. Nevertheless, Louis Brandeis, other social reformers, M.D.'s and state legislatures appear to have been right when they asserted that long hours of work under adverse circumstances were a threat to health. Much of the scientific evidence, however, was to come later as a result of systematic investigations into the effects of efforts to raise output through increased hours of work during World War I and World War II. To the extent that such long hours and poor working conditions harmed just the individual worker's health 
though, it is hard to make a convincing case for the regulation of hours and conditions in the workplace as a public, as opposed to private, health question. Such a link can, however, be made to children through the health of the mother. Unhealthy mothers give birth to unhealthy children and some substances such as heavy metals cross the placenta and inhibit or harm fetal development. The public has had an interest in the welfare of children since time immemorial. This threat therefore provides adequate justification for state intervention even when the Courts rule, as in the case of INTERNATIONAL UNION, UAWV. JOHNSON CONTROLS INC., that such conditions do not justify private intervention. Not surprisingly, it was this concern that eventually motivated intervention, first in COMMONWEALTH V. HAMILTON MANUFACTURING COMPANY and eventually in MULLER V. $O R E G O N$. Even for men, a case can be made for intervention and regulation in the interest of public health to the extent that the fatigue from long hours and insults to well-being such as dust, enervating heat, and toxic fumes weakened resistence to disease, especially communicable diseases such as tuberculosis or pneumonia. Indeed precisely such a case was made in the reincarnation of the Brandeis brief in BUNTING V. OREGON. 